\title{
Unfulfilled Diplomacy: The U.S.-DPRK Relationship and the Agreed Framework
}

\author{
Patricia Su-he Randolph \\ Falls Church, Virginia
}

Bachelor of Arts, Political Science, Virginia Polytechnic Institute, 2007

A Thesis presented to the Graduate Faculty

\begin{abstract}
of the University of Virginia in Candidacy for the Degree of
\end{abstract}
Master of Arts

\section{East Asian Studies}

University of Virginia

August 2013 


\section{Contents}

ABBREVIATIONS \& ACRONYMS.

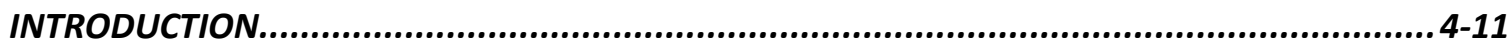

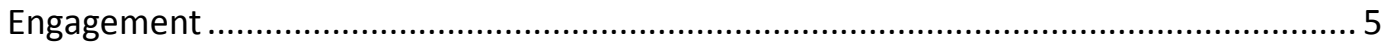

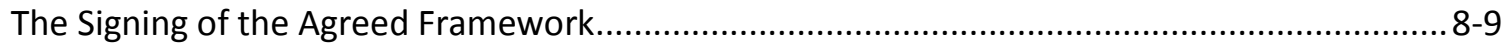

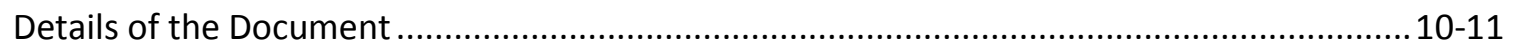

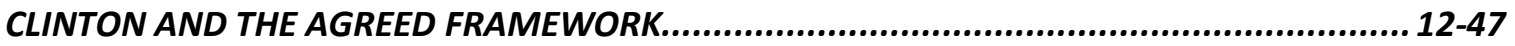

Paragraph I: LWRs, Heavy Oil, Assurances \& KEDO....................................................... 13-19

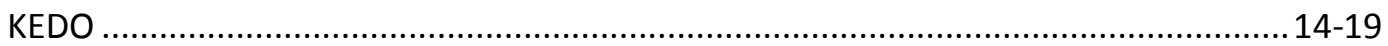

Paragraph II: Diplomatic and Economic Normalization ..............................................20-28

Economic Restrictions on North Korea ..................................................................20-21

Reduction of Economic Barriers …......................................................................21-23

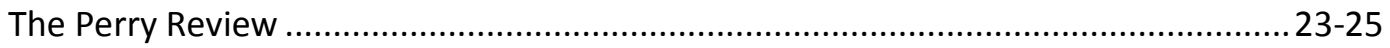

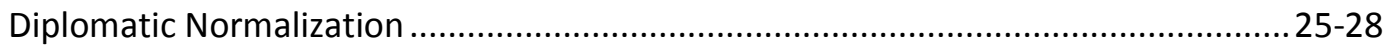

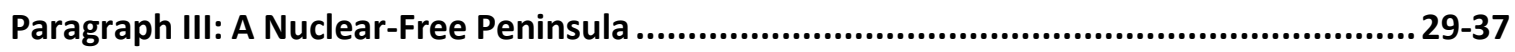

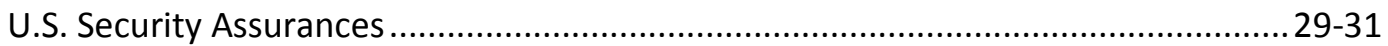

The Four Party Peace Talks .................................................................................... 31-34

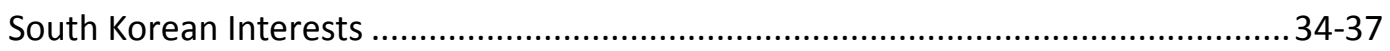

Paragraph IV: The IAEA and North Korean Cooperation.................................................38-43

The Freeze and Dismantlement ..............................................................................39-40

LWRs in Exchange for the Freeze ................................................................. 40-41

Quid Pro Quo Progress............................................................................. $42-44$

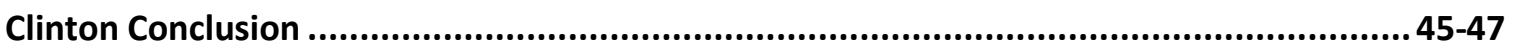

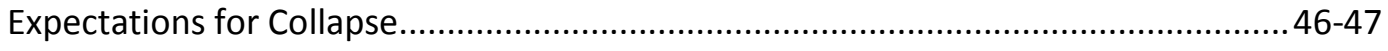

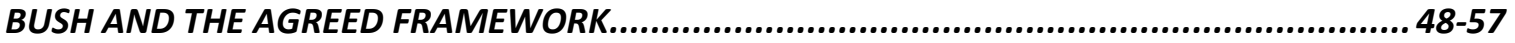

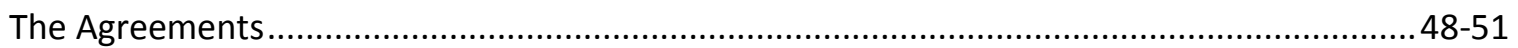

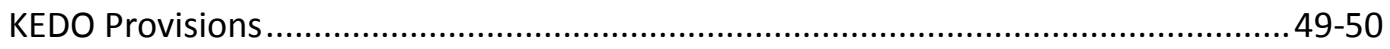

Economic Barriers and Diplomatic Normalization .......................................................... 50

U.S. Security Assurances, The "Axis of Evil," and 9/11 ..........................................50-51 


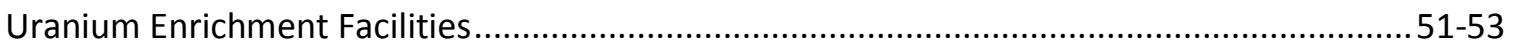

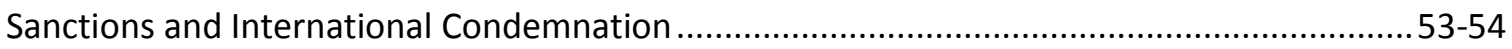

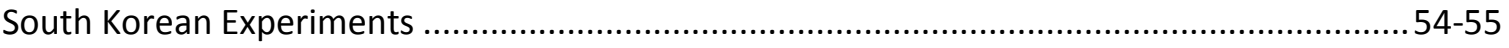

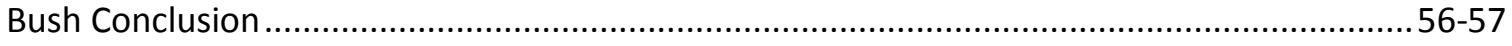

THE COLLAPSE OF THE AGREED FRAMEWORK .....................................................58-60

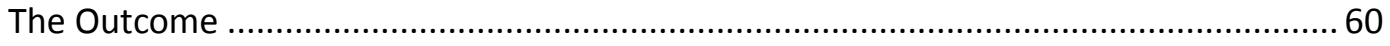

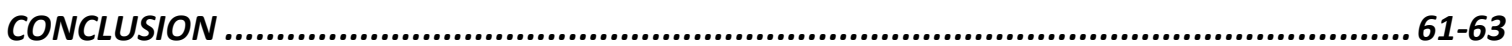




\section{ABBREVIATIONS \& ACRONYMS}

$\begin{array}{ll}\text { DMZ } & \text { Demilitarized Zone } \\ \text { DPRK } & \text { Democratic People's Republic of Korea } \\ \text { HFO } & \text { Heavy Fuel Oil } \\ \text { IAEA } & \text { International Atomic Energy Agency (of the United Nations) } \\ \text { KEDO } & \text { Korea Peninsula Energy Development Organization } \\ \text { LWR } & \text { Light-Water Reactor } \\ \text { NATO } & \text { North Atlantic Treaty Organization } \\ \text { NPT } & \text { Non-Proliferation Treaty } \\ \text { ROK } & \text { Republic of Korea } \\ \text { UN } & \text { United Nations }\end{array}$




\section{Introduction}

The Democratic People's Republic of Korea (DPRK) and leader Kim Jong Il have often been portrayed as the antagonists of the East. Some of the words that have been used to classify North Korea are "rogue,"1 "dangerous,",2 and most notably, a member of an "axis of evil." These titles all allude to the idea that under the leadership of the Kim family, North Korea is both unpredictable and untrustworthy in its foreign affairs. However, when past actions on both sides of U.S.-DPRK negotiations are closely analyzed, there is observable evidence that the contrary is true. I argue that from the signing of the Agreed Framework in 1994 to its collapse in 2003, there has been consistent evidence that Pyongyang has responded favorably to positive engagement by the United States.

Furthermore, based on the U.S. handling of the Agreed Framework there is validity in the DPRK's apprehension in dealing with the United States. Due primarily to schisms within the U.S. government and inconsistent policies towards North Korea, the U.S. has been unable to carry forward engagement policy with the DPRK. When one looks back at several poorly handled incidents in history ${ }^{4}$ and specifically failure to uphold the agreements made under the 1994 Agreed Framework, it is clear that the United States is also a contributor to the long-term animosity that looms over U.S.-DPRK dealings.

The purpose of this thesis is twofold: 1) to bring to light the incidents where the U.S. strayed from or was unable to carry forward agreements made with North Korea and thereby contributed to the breakdown of the engagement process, and 2) to show that 
there have been several incidents where Pyongyang has responded favorably to positive engagement by the United States between 1994 and 2003.

My arguments differ from the works of leading academics in Korean studies because I provide a detailed and comprehensive study of how the Agreed Framework was implemented through extensive research of U.S. government documents (to include declassified U.S. intelligence), official North Korean press releases and United Nations testimony, in addition to news and academic sources. Furthermore, I do not assess whether or not engagement policy was a success or a failure, but instead state that we cannot make this assessment because there has yet to be a sincere attempt to engage North Korea and the window to do so has passed.

\section{Engagement}

"Engagement" is somewhat of an ambiguous term. Often when it is used in regard to the U.S.-DPRK relationship a definition is omitted. ${ }^{5}$ The inferred definition of engagement is that it is simply the opposite of the status quo; prior to 1994 few incidents of positive interaction occurred between the two countries and the relationship was largely based on a mutual hostility. ${ }^{6}$ Thus, "engagement" is a relatively new concept when applied to the U.S.-DPRK relationship.

For the sake of clarity, this thesis will define "engagement" according to an explanation by Victor Cha. In his 2002 essay, "Engaging North Korea Credibly," Cha states that,

"Engagement is a process of strategic interaction designed to elicit cooperation from an opposing state. Its means are generally non-coercive and non-punitive, seeking neither to undercut an adversary nor to pressure it into submission. The strategy also differs from capitulation as it does not entail simply deferring to the opponent's desires, but seeks some form of accommodation. However, engagement is more than everyday 
diplomacy. It is a discrete type of security response to a threatening power, actively seeking to transform the relationship into a non-adversarial one and to change the threatening state's behaviour and goals in the process. Arguably, containment could be described in a similar way. Moreover, engagement is not credible to the opponent without some semblance of strength on the part of the engager. The primary difference, however, is that engagement does not explicitly leverage the threat of conflict or punishment to exact cooperation."7

The signing of the Agreed Framework in 1994 marks the commencement of U.S. engagement policy with North Korea and was a significant shift from past U.S. policy. However, it equally marks the commencement of a new North Korean policy towards the United States since engagement cannot exist without the consent and cooperation of both parties.

There are varied opinions as to why the DPRK has had a positive response to U.S. attempts at engagement and in turn opened its own foreign policy toward the United States from the early 1990 s forward. Views on the matter differ, ranging from belief that North Korea has a true desire for reform, ${ }^{8}$ North Korea is attempting to subdue the forces that threaten it while secretly building up its weapons programs, ${ }^{9}$ and North Korea is attempting to get as much aid and assistance as possible by feigning desire for reform. ${ }^{10}$ It is difficult to ascertain the true intentions behind Kim Jong Il's compliance; a series of natural disasters during the 1990s and decades of strict abidance to the DPRK's homecrafted juche $e^{11}$ ideology have resulted in long-term economic plight and stunted foreign relations.

However, despite this uncertainty, Kim Jong Il has displayed a pattern of relatively consistent behavior in his foreign policy towards the United States. Under the rule of Kim Jong Il, the DPRK stance has usually been open and receptive to U.S. attempts at engagement and there have been several examples of North Korean 
compliance with agreements involving the United States since the signing of the 1994 Agreed Framework.

However, when U.S.-DPRK relations revert back to stalemate or hostility, the global response is usually to highlight where the DPRK is at fault, without considering the U.S. role in the standstill. Often suspicions arise over whether North Korea ever really intended to carry forward agreements made with the United States, or if it was all a ploy to maintain regime survival. However, when assessing the success of U.S.-DPRK relations, an equally important question to ask is: has the United States truly favored an engagement policy with North Korea?

The answer is both "yes" and "no." Foreign policy towards North Korea has been a highly divisive issue among U.S. policymakers, analysts and scholars alike. The agreements made under the auspices of the Agreed Framework and the series of negotiations that have followed in the aftermath reveal how ineffective U.S. attempts at engagement have been as a result of the political divides and inconsistent policies within the American bureaucracy.

Both parties have contributed to the engagement and then confrontation foreign policy rollercoaster that has been so visible in the international media. However, the divisions and fluctuations in U.S. policy should not be underplayed, as they have largely served as a catalyst for both U.S. and DPRK hostilities. A thorough review of the Agreed Framework and how the agreements were upheld in the decade after its signing will provide an objective description of the first formalized attempt at engagement with North Korea and the DPRK stance towards U.S. engagement policy under Kim Jong Il. 


\section{The Signing of the Agreed Framework}

"...General James Clapper, who was director of the Defense Intelligence Agency (DIA) during the 1994 North Korean nuclear crisis, has said that 'personally as opposed to institutionally, I was skeptical that they ever had a bomb. We didn't have smoking gun evidence either way. But you build a case for a range of possibilities. In a case like North Korea, you have to apply the most conservative approach, the worst-case scenario."'12

Suspicious construction activity was first observed at Yongbyon, North Korea in April 1982. ${ }^{13}$ As construction progressed at the site — about sixty miles north of Pyongyang — further evidence supporting the idea that a plutonium-processing facility was being built at Yongbyon was developing. ${ }^{14}$ However, intelligence officials remained uncertain about several aspects of the site. For instance, the facility also fit the mold for several other types of plants, including a chemical fiber factory. Furthermore, if the site at Yongbyon actually was being used to process plutonium, then it seemed odd that the DPRK would leave the facility unconcealed, as no efforts were made to disguise or cover the area and the plant was easily visible from overhead. ${ }^{15}$ In essence, even by the late 1980s and early 1990s, the data remained inconclusive as to whether or not a nuclear weapons facility existed at the site.

However, news that North Korea could possibly produce atomic bombs by the mid-1990s reached international airways in May 1989, following a high-level meeting between U.S. and South Korean officials. ${ }^{16}$ As worldwide attention was brought to the unconfirmed facility at Yongbyon, tensions between the DPRK and the United States grew as panic over what could possibly exist at the site spread.

Shortly after President Bill Clinton entered office in January 1993, the "nuclear crisis" on the peninsula had escalated to the brink of war ${ }^{17}$ and further conflict was averted only after an impromptu visit to North Korea by former President Jimmy Carter 
in June 1994. ${ }^{18}$ Things cooled down during the Carter visit, during which Kim Il Sung made it known that he hoped to avoid war and was open to negotiations over the suspected plutonium-processing facilities, which had been the source of so much controversy. Kim Il Sung died shortly thereafter in July 1994, but not before the basic outline of the Agreed Framework had been laid out through a series of bilateral talks following the Carter visit. ${ }^{19}$ Negotiations continued after Kim's death and eventually led to the signing of the Agreed Framework, which was perhaps the most monumental agreement between the United States and North Korea since the signing of the 1953 Korean War Armistice Agreement several decades before. ${ }^{20}$ Kim Il Sung's son and successor, Kim Jong Il, carried forward the agreement under his leadership, ushering in a new era of bilateral engagement between the two countries. 


\section{Details of the Document}

The Agreed Framework is a bilateral agreement between the United States and the Democratic People's Republic of Korea signed on October 21, 1994. The negotiations preceding it were held in Geneva from September $23^{\text {rd }}$ to October $21^{\text {st }}$ with the purpose of resolving "the nuclear issue on the Korean Peninsula." 21 It was a major step in U.S.DPRK relations and a peaceful resolution to a potentially volatile situation.

The Agreed Framework contains four paragraphs, each containing three to four subparagraphs and is fairly short, numbering only four pages. However, despite the brevity of the document, the arrangements made under the auspices of the Agreed Framework were momentous. In exchange for the freezing and eventual shutdown of specific plants in North Korea, the U.S. agreed to the following: to eventually provide the DPRK with fully functioning light-water reactor (LWR) power plants ${ }^{22}$ and to supply heavy oil during the interim between the freeze of suspected North Korean facilities and the activation of the LWRs. To provide funding for North Korean provisions, the U.S. would create an "international consortium" and serve as the primary point of contact for the organization. In addition, the U.S. would provide formal assurances ${ }^{23}$ to the DPRK that the LWR project would be carried through and that the United States would not use its own nuclear weapons to threaten or harm North Korea once the freeze of DPRK facilities had begun. ${ }^{24}$

North Korea agreed to freeze its "graphite-moderated reactors and related facilities" 25 at Yongbyon and to allow the United Nations International Atomic Energy Agency (IAEA) inspectors back into North Korea with full adherence to the Non- 
Proliferation Treaty (NPT) and IAEA standards. ${ }^{26}$ Once the freeze had begun, the DPRK would work together with the United States to dispose of spent fuel rods in an agreed upon manner, following U.S.-DPRK expert-level discussions. The DPRK would be required to make a nuclear declaration of all facilities in the country and eventually verify their nuclear history with IAEA inspection and confirmation as the LWR project neared completion, in addition to dismantling the graphite-moderated reactors and related facilities at Yongbyon. The Agreed Framework also mandated that North Korea engage in dialogue with the Republic of Korea (ROK) and begin implementing the bilateral North-South denuclearization declaration signed between the two Koreas in $1992 .^{27}$ Lastly, both sides agreed to remove economic barriers and establish diplomatic relations with each other, eventually leading to full-scale normalization. ${ }^{28}$

The Agreed Framework provided a basic structure for U.S.-DPRK relations through the 1990s and into the early 2000s. It marked the commencement of U.S.-DRPK engagement and was a major step in bilateral relations between the two countries, although it proved to be very controversial for both sides. Both countries made lofty agreements in an effort to secure peace and stability on the peninsula that were only partially fulfilled when the Agreed Framework fell apart in 2003. Analysis of the Agreed Framework and its implementation will reveal how both parties shaped and hindered the success of the agreement through the 1990s and into the new millennium. 


\section{Clinton and the Agreed Framework}

The Bill Clinton Administration began January 20, 1993 and ended January 20, $2001 ;^{29}$ during these eight years, U.S.-DPRK relations reached new heights. Once the military tensions on the peninsula were defused in late 1994, the U.S. took a fresh stance towards North Korea under President Clinton, who favored a pro-engagement policy for the duration of his two terms in office. However, President Clinton's attempts at engagement and the Agreed Framework may have promised too much and may have been too ambitious for U.S. policymakers at the time.

The Agreed Framework was negotiated without the consent of the U.S. Congress $^{30}$ and although it achieved the immediate goal of freezing North Korea's possible plutonium-processing facilities and helped both countries to avoid a destructive and high-casualty war, ${ }^{31}$ further progress was limited. The checks and balances present in the U.S. government were not ready for such an unrestrained relationship with North Korea.

Thus, with limited time and opposition from critics within the U.S. government, the Clinton Administration was unable to fulfill all of the agreements made with the DPRK under the Agreed Framework and contributed to the eventual breakdown of negotiations between the two countries. There are several examples where this was the case. 


\section{Paragraph I: LWRs, Heavy Oil, Assurances \& KEDO}

The first point of the Agreed Framework states that "Both sides will cooperate to replace the DPRK's graphite-moderated reactors and related facilities with light-water reactor (LWR) power plants." ${ }^{32}$ Instead of introducing the document with the requirements that North Korea must fulfill in order to attain the benefits that the United States has accorded - for example, the freezing of the graphite-moderated reactors at Yongbyon — the first point of the Agreed Framework places a high priority on the LWRs, making the United States responsible for the first and primary task under the Framework.

Paragraph I also states that, "Upon receipt of U.S. assurances for the provision of LWR's and for arrangements for interim energy alternatives, the DPRK will freeze its graphite-moderated reactors and related facilities and will eventually dismantle these reactors and related facilities." 33 The purpose of this subparagraph is to state that only when the United States has demonstrated that it will uphold its part (the LWRs and heavy oil supplements) should the DPRK freeze and later begin dismantling their suspected nuclear facilities. However, they are not obligated to act unless the U.S. has met its part of the agreement first. It is important to note that the document is negotiated so that North Korea receives specific assurances from the United States before it is required to make any progress on the agreement.

By agreeing to take the first step, the U.S. may have attempted to establish a new degree of trust with North Korea. Critics of the Agreed Framework have called this “appeasement." 34 However, it was necessary for the U.S. to provide assurances to North 
Korea, who apprehended that the United States would keep its promises in the long-term. Further assurance that the LWR project would be carried through was provided in a letter from President Clinton to Kim Jong Il one day prior to the signing of the Agreed Framework. ${ }^{35}$ In the letter, President Clinton promised to use the "full powers" of his office to fulfill U.S. obligations relating to the LWRs and heavy oil, as long as the DPRK continued to implement the policies described in the Agreed Framework. ${ }^{36}$ Direct assurance from the President of the United States that the LWR project would be carried through undoubtedly carried a lot of weight with DPRK negotiators. Unfortunately, despite cooperation from Pyongyang, the assurances described in President Clinton's letter and reiterated in the Agreed Framework did not result in light-water reactors for the DPRK.

KEDO

Under the Agreed Framework, the U.S. agreed to provide North Korea with LWRs having "a total generating capacity of approximately 2,000 MW(E) by a target date of $2003^{\prime 37}$ and to provide 500,000 tons of heavy oil annually until the completion of the first LWR, beginning within three months of the signing of the Framework. The purpose of the heavy oil deliveries would be to "offset the energy foregone due to the freeze of the DPRK's graphite-moderated reactors and related facilities.",38

The cost of both the LWRs and heavy oil would amount to millions of dollars annually and billions over time. ${ }^{39}$ U.S. negotiators had the foresight to make the financing of the LWRs and heavy oil reliant on an "international consortium" and thereby a multilateral endeavor. ${ }^{40}$ The Korean Peninsula Energy Development Organization 
(KEDO) was established in March 1995 for this purpose; the original members included the United States, South Korea and Japan. ${ }^{41}$ Under the KEDO charter, member states would make decisions regarding funding as a part of an Executive Board, but the United States would serve as the primary point of contact for the DPRK with the LWR project and oversee all major decisions. ${ }^{42}$

KEDO got off to a slow start. The U.S. promised to make "best efforts" to conclude a supply contract for North Korean provisions within six months of the signing of the Agreed Framework. ${ }^{43}$ However, it was more than a year after the signing of the Framework and seven months after KEDO was created that the supply contract was finally signed between KEDO and the DPRK in December $1995{ }^{44}$ In the two years immediately following the signing of the Agreed Framework, North Korea received a total of 650,000 tons of heavy oil, much less than the 500,000 tons per year that was agreed upon. ${ }^{45}$ After 1996 steady progress was made on the heavy oil deliveries, although deliveries were often not on schedule or quantified in the same amount each time. ${ }^{46}$ From 1997 through 2000 North Korea received 1.89 million tons of heavy oil, about 500,000 tons a year. $^{47}$

The reduced supply of heavy oil from 1995-1996 was most likely a result of KEDO funding issues. Despite contributions from numerous countries, ${ }^{48} \mathrm{KEDO}$ struggled to raise the necessary amount of capital early on. It was primarily South Korea and Japan who shouldered the burden of these financial difficulties. An additional contribution from Japan is noted in a declassified State Department report from May 1996, which states, 
“Most importantly, Japan's special fund contribution of \$19 mil. greatly eased KEDO's short term funding crisis this spring. While we have made important progress in securing international support, KEDO still needs an additional \$8-10 million this year to continue its HFO shipments past September. We are working cooperatively to overcome these funding difficulties, but KEDO can still not see its way to funding all fuel shipments required this year., 49

Even after an additional contribution from Tokyo, KEDO still struggled to make the HFO deliveries, as North Korea only received 650,000 tons of oil for 1995 and 1996 combined. $^{50}$ The same State Department report noted the frustrations of South Korea and Japan, stating that, "Japan and Korea have been concerned about what they see as signs of waning USG financial commitment to KEDO." ${ }^{31}$ The situation described by State Department officials in 1996 was not an isolated occurrence. It would not be the last time that Japan and South Korea would have to compensate for U.S. shortcomings when it came to KEDO funding. This trend continued into the new millennium, although all three governments experienced difficulty obtaining support to fund the multi-billion dollar LWR project and the heavy oil shipments.

Throughout KEDO's existence, the majority of funding came from South Korea, who provided $70 \%$ of KEDO funds when it was first launched in $1995^{52}$ and $\$ 1.36$ billion over time (1995-2004). ${ }^{53}$ Japan, the second largest contributor to KEDO, invested more than $\$ 480$ million over the same time period. ${ }^{54}$ Of the original KEDO members, the United States contributed the least, providing \$405 million to KEDO from 1995 to $2004 .^{55}$

It is unclear how large of a role the negotiators of the Agreed Framework intended for the United States to have in the financing of the heavy oil and the LWRs. However, funding difficulties surfaced almost immediately as a result of divisions within the federal 
government and a lack of consensus on how to conduct foreign policy towards North Korea.

Shortly after the signing of the Agreed Framework, the balance of power shifted in Washington when the Republicans won the congressional elections in November 1994 and the Democrats lost control of both houses. ${ }^{56}$ A Republican majority prevailed through the remainder of the Clinton Administration, winning the $105^{\text {th }}$ and $106^{\text {th }}$ congressional elections, in addition to the 104th. According to Stephen Bosworth, the first executive director of KEDO, "Within 10 days after the framework was signed, it became a political orphan...conservative Republicans, particularly in the House, who hated the Agreed Framework, believed that it was basically an example of the U.S. paying extortion, began to oppose it very fiercely." ${ }^{, 57}$ Thus, despite the Clinton Administration's best intentions, approval for funding the LWR project and heavy oil quickly became difficult to obtain in the newly elected Republican-dominated Congress. At an estimated $\$ 4.7$ billion total, ${ }^{58}$ the LWRs proved to be much more of an issue for KEDO than the HFO shipments and the project significantly lagged behind the timeline that was agreed upon. The United States in particular, was unwilling to dole out large amounts of cash for the project; the majority of U.S. funding went towards heavy oil shipments and KEDO administrative expenses, very little was actually invested in the LWR project. ${ }^{59}$ As a result of funding troubles, the KEDO ground-breaking ceremony for preliminary construction work at the work site in Kumho, North Korea, did not occur until August $1997^{60}$ and the contract for the construction of the LWRs, signed by KEDO 
and the Korean Electric Power Corporation (KEPCO), did not become effective until early $2000 .^{61}$

By the end of the Clinton Administration in January 2001, construction of the LWRs was in the very basic stages. At most grading of the construction site had begun. ${ }^{62}$ The 2003 target date was becoming increasingly unrealistic by this point. North Korean faith in the Clinton Administration to carry forward the agreement had begun to dwindle by the late 1990s and the DPRK released the following statement in their state-run press in March 1998,

The U.S. "has made little progress in the construction of light-water reactors under the pretext of internal problems within the KEDO such as sharing of funds, though it is more than two years since the LWR supply agreement was adopted. We cannot but express deep concern over this insincere attitude of the U.S. toward the implementation of the framework agreement...it does not make any sense to victimise our independent nuclear power industry continuously with hopes pinned on the light-water reactors that are not sure to come. Nobody can predict what will happen unless the U.S. seeks new practical measures and takes decisive action to implement its obligations under the agreement as scheduled." 63

The potential to improve relations by adhering to the Agreed Framework was deteriorating as North Korea began to seek alternative ways to obtain what was promised by the United States. Difficulty with funding resulted in delays in the construction of the two light-water reactors and from the North Korean perspective has been a source of hostile behavior on their part. However, while the reduction in heavy oil and the delay on the LWR project resulted in somewhat provocative rhetoric from the DPRK, North Korea's graphite-moderated reactors remained frozen throughout the Clinton Administration and the primary agreement on the DPRK side was upheld. The lack of follow through on the most tangible aspects of the Agreed Framework led to the eventual deterioration of relations between the United States and the DPRK when paired with the 
other unfulfilled areas of the Framework and should not be underplayed when assessing the breakdown of the agreement. 


\section{Paragraph II: Diplomatic and Economic Normalization}

\section{Economic Restrictions on North Korea}

The second paragraph of the Agreed Framework states that "The two sides will move towards full normalization of political and economic relations." ${ }^{64}$ The economic barriers that were in place were largely one-sided because of the economic disparity between the two countries and because it was the U.S. who had implemented numerous unilateral sanctions and other economic restrictions against North Korea since the beginning of the Korean War in $1950 .{ }^{65}$ Thus, reducing economic barriers was a task primarily directed towards the United States and had little to do with North Korea reciprocating the action.

According to congressional research specialists, U.S. economic sanctions have been imposed against North Korea for four primary reasons: “(1) North Korea is seen as posing a threat to U.S. national security; (2) North Korea is designated by the Secretary of State as a state sponsor or supporter of international terrorism; (3) North Korea is a Marxist-Leninist state, with a Communist government; and (4) North Korea has been found by the State Department to have engaged in proliferation of weapons of mass destruction." ${ }^{, 66}$ In accordance with these constraints the United States has imposed a nearly complete economic embargo on North Korea, ${ }^{67}$ limited aid, and opposed North Korean entry into international financial institutions over the last half a century. ${ }^{68}$ As a result of severe trade restrictions, the trade relationship between the United States and North Korea has been relatively insubstantial. Bilateral trade fluctuated during the Clinton Administration, but in general remained low; U.S. foreign trade statistics 
document a low of $\$ 180,000$ in 1994 and a high of $\$ 11$ million in $1999 .{ }^{69}$ However, from 1994 to 2001 bilateral trade totaled less than \$5 million each year, with the exception of 1999, following the 1998 missile crisis. ${ }^{70}$

\section{Reduction of Economic Barriers}

"Full economic normalization" was the overall goal stipulated in the Agreed Framework, however paragraph II also required both parties to take a preliminary step, stating that within three months of the signing of the document "both sides will reduce barriers to trade and investment, including restrictions on telecommunications services and financial transactions." ${ }^{, 71}$ In January 1995, North Korea announced that it was lifting both bans ${ }^{72}$ and the United States followed suit shortly thereafter, meeting the three month deadline one day in advance. ${ }^{73}$

The changes were minor; the U.S. agreed to unblock some of North Korea's frozen assets, and both agreed to make arrangements for direct phone calls between the two countries and to allow Americans traveling in North Korea to use credit cards while in country. ${ }^{74}$ These changes did little to ease the wide range of economic restrictions imposed on North Korea and the trade relationship between the United States and the DPRK remained severely inhibited after 1995. One State Department official described the changes as "relatively limited, relatively modest first steps." 75

Several years passed before any further progress was made on economic normalization between the United States and the DPRK. By 1996 North Korea had begun to express concern about the progression of the agreement, reminding the U.S. about its promise to alleviate the economic restrictions that remained firmly in place. A 
State Department report noted "increasing stress by DPRK officials...on the need for US to ease sanctions, provide food aid and in general provide economic benefits to the DPRK."76 At the time of this State Department report, the situation in North Korea was becoming increasingly desperate. The 1990 s was a transitional decade for the DPRK when several key events occurred that significantly affected the domestic atmosphere in North Korea. Most notably, the DPRK lost support from communist allies as the Cold War came to an end; the first leadership change in North Korean history took place in July $1994 ;^{77}$ and the country experienced several consecutive devastating natural disasters, which destroyed much of North Korea's infrastructure, damaged key industries and lead to widespread famine.

However, despite the growing domestic turmoil, it should be noted that in 1996, the DPRK expressed concerns about the pace of economic normalization calmly, through the use of dialogue and via official channels with the United States. Unfortunately, the Clinton Administration did not take any measures to fulfill the agreements outlined in paragraph II and help to mitigate the situation in North Korea.

Nearly four years after the signing of the Agreed Framework, North Korea took a different approach to negotiations. Citing the lack of progress on the LWR project and the stagnant state of economic and diplomatic normalization efforts, North Korea test fired its medium-range Taepodong 1 rocket in August 1998. The missile passed over Honshu and then fell into Japanese waters. ${ }^{78}$ The launch of the rocket came as a surprise to Japan and its allies because no immediate forewarning was given. ${ }^{79}$ However, the outcome of the missile launch was that the U.S. agreed to ease most export-related 
restrictions in response to North Korea's willingness to sign a temporary moratorium and cease missile testing in the negotiations that followed in the aftermath. ${ }^{80}$ Thus, the firing of missiles achieved the goal of bringing the U.S. back to the table to seriously consider steps toward diplomatic and economic normalization.

\section{The Perry Review}

After the missile launch President Clinton and his national security advisors tasked a North Korea policy review team "to conduct an extensive review of U.S. policy toward the DPRK" in November 1998. The review lasted eight months and was led by William Perry, the Special Advisor to the President and the Secretary of State. Over the course of the review, the team consulted with both U.S. government and non-government experts, met with ROK and Japanese officials, and traveled to North Korea as President Clinton's special envoy in May 1999. ${ }^{81}$ At the end of the review, the team published their findings in a report titled, Review of United States Policy Toward North Korea: Findings and Recommendations. (Hereinafter referred to as the "Perry Review.")

At the recommendation of the Perry Review, the U.S. attempted to persuade North Korea to give up its missiles program by repackaging promises that had already been included under the Agreed Framework. The Perry Review stated that "If the DPRK moved to eliminate its nuclear and long-range missile threats, the United States would normalize relations with the DPRK, relax sanctions that have long constrained trade with the DPRK and take other positive steps that would provide opportunities for the DPRK." 82 These offers were already included in the Agreed Framework, but the U.S. 
used it as leverage during the missile crisis, despite the fact that North Korea had been in compliance with the Framework at the time of the Perry Review.

William Perry and his staff members took the view that North Korea had been given too much under the Agreed Framework, noting that, "The approach recommended seeks more than the Agreed Framework provides," not offer the DPRK tangible 'rewards' for appropriate security behavior; doing so would both transgress principles that the United States values and open us up to further blackmail." ${ }^{84}$ Like many U.S. policymakers during the Clinton Administration, Perry found the Agreed Framework to be disproportionately in favor of the DPRK. Although the agreement had been in place for nearly five years at the time of the Perry Review, the United States continued to backslide on agreements with North Korea because U.S. policymakers held the Framework in such disdain.

The North Korean missile launch gave the DPRK the opportunity to address the slow progressing aspects of the Agreed Framework with the U.S., but also allowed the United States to expand outside the boundaries of the Agreed Framework by insisting that the DPRK take further steps to obtain U.S. provisions and benefits, despite North Korean adherence to the agreements under the Framework.

Although the missile launch served as a catalyst for economic change between the two countries, the U.S. made minimal efforts to ease sanctions in the aftermath of the launch. The easing of sanctions in $2000,{ }^{85}$ while a relatively large jump forward when compared to the economic restrictions existing prior to the late 1980s, was still a far cry from "full economic normalization." In 2000, six years from the signing of the Agreed 
Framework, the U.S. allowed imports from North Korea for the first time during the Clinton Administration, albeit on a small-scale. North Korean exports to the United States totaled $\$ 154,000$ in 2000 and $\$ 20,000$ in $2001{ }^{86}$ Restrictions surrounding North Korea's status on the U.S. terrorist list and those relating to proliferation remained in place, which obstructed North Korea from engaging in most trade activity. ${ }^{87}$

The potential reduction of economic barriers was undoubtedly great incentive for the DPRK to freeze its graphite-moderated reactors and sign the Agreed Framework. The 1990s was a time of great domestic turmoil in the DPRK and the desperation of the country was apparent as North Korea accepted millions of metric tons in food aid from countries all over the world, but still dealt with widespread famine across the country. ${ }^{88}$ The U.S. was well aware of the North Korean plight, noting in the Perry Review that, “The DPRK appears to value improved relations with US, especially including relief from the extensive economic sanctions the U.S. has long imposed." 89

However, despite serious talks to ease sanctions in the aftermath of the missile launch and President Clinton's power to abolish many of them by executive order, the U.S. was hesitant to implement any kind of substantial change to the economic relationship in order to maintain peace on a bipartisan level.

\section{Diplomatic Normalization}

Paragraph II also calls for the eventual, full-scale normalization of diplomatic relations between the United States and the DPRK. Diplomatic normalization with the United States is something that North Korea has desired for decades. Largely because of the rivalry between the North and South Koreas, but perhaps more importantly as a way 
to ease the very real threat that the U.S. radiates across the demilitarized zone (DMZ) that separates the two Koreas.

As a primary step, both countries agreed to open a liaison office in the other's capital, after making "a resolution of consular and other technical issues through expert level discussions." 90 Paragraph II goes on to state that, "As progress is made on issues of concern to each side, the U.S. and DPRK will upgrade bilateral relations to the ambassadorial level." 91

Throughout the course of the Clinton Administration, U.S. and DPRK officials engaged in expert level talks over the possibility of diplomatic relations, but to no avail. ${ }^{92}$ Ambassadors were never exchanged and even the preliminary step to establish liaison offices in Pyongyang and Washington never occurred. ${ }^{93}$ Of all the agreements made under the Agreed Framework, the least amount of progress was made on the issue of diplomatic normalization. It is apparent from the lack of progress on the points outlined in the second paragraph, that engagement with North Korea remained an uncomfortable concept for the United States and was more difficult to apply in actuality than the negotiators of the Framework had anticipated.

Normalization efforts were lagging from the start and North Korea expressed concern about the pace of normalization and the furthering of diplomatic relations early on. A State Department report from 1996 noted that, "progress on the bilateral USDPRK aspects of the Framework has been spotty and halting. Remains and missile talks are positive developments. The impasse on Liaison Offices continues. The North has criticized the US for not meeting its commitment in the Agreed Framework to gradually 
normalize economic relations as progress has been made on other issues. They have a valid point."94 Unfortunately the slow progress on diplomatic normalization acknowledged by the U.S. government in 1996 remained applicable through the entirety of the Clinton Administration.

By making no headway on the normalization of diplomatic relations on even a small scale, the U.S. sent a message that hostility and mistrust remained a very palpable issue between the two countries. Meanwhile, steady cooperation from Pyongyang in implementing the Agreed Framework made the situation even more disparaging. Instead of actively trying to engage North Korea in the manner put forth under the Agreed Framework, the furthering of diplomatic relations often came up as a negotiating card for the United States during talks with North Korea, even over issues that occurred outside the scope of the Agreed Framework. ${ }^{95}$

However, despite the stagnant state of diplomatic affairs during the Clinton Administration, there were still relative improvements to bilateral relations when compared to the U.S.-DPRK relationship during the Cold War era. Aside from the occasional flair-up, dialogue between North Korea and the United States continued moreor-less unimpeded, even if discussions were hostile in nature at times. In addition, the highest level visit from a U.S. official to the DPRK occurred in October $2000,{ }^{96}$ when Secretary of State Albright visited North Korea as a precursor to a potential visit by President Clinton. ${ }^{97}$ The visit can largely be attributed to the 1998 missile launch, which remained a top issue during the Secretary's visit. ${ }^{98}$ Secretary of State Albright met 
directly with Kim Jong Il while in North Korea and the media reported that the visit was amiable and well-received on both sides. ${ }^{99}$

President Clinton also planned to make a trip to North Korea towards the end of his second term in office, ${ }^{100}$ but the highly publicized and would-be historic visit never occurred; primarily because of the large scale opposition in the American bureaucracy, but also because the Clinton Administration had not been able to secure a missile agreement with North Korea in advance, which continued to be utilized as a leverage tool in negotiations. The trip had likely been proposed in the first place to entice the DPRK into making a more permanent deal over its missiles program. ${ }^{101}$

Although some strides were made in bilateral relations during the Clinton Administration, the normalization of diplomatic relations remained entrenched in the same state of affairs as prior to the signing of the Agreed Framework. By ignoring a key clause of the Framework, the U.S. impaired the further development of bilateral relations with the DPRK at a time when North Korea may have been at its most debilitated state. Steps toward diplomatic normalization with the United States would have inadvertently provided North Korea with security assurances by making the relationship less adversarial, and would have simultaneously opened up economic opportunities with the United States and other countries. With the cooperation of Congress, the Clinton Administration could have taken steps to drastically alter the U.S.-DPRK relationship for the better, but the lack of consensus on how to conduct foreign policy toward North Korean proved to be a very large hindrance towards taking any steps forward. 


\section{Paragraph III: A Nuclear-free Peninsula and U.S. Security Assurances}

The third paragraph of the Agreed Framework states, "Both sides will work together for peace and security on a nuclear-free Korean Peninsula."102 The document shies away from any direct reference to North Korea's possible plutonium-processing facilities, but instead indirectly addresses the DPRK nuclear issue by asserting that "both sides" will make an effort to establish a nuclear-free peninsula. The Agreed Framework in general is cautious in its wording, ambiguously referring to the suspected plutoniumprocessing facilities as "graphite-moderated reactors," throughout the document, which can be used for electricity generation or as a part of a nuclear weapons facility. The ambiguity of the document indicates the delicate nature of negotiations and how important it was to approach the situation without declaring outright that North Korea was developing nuclear weapons. By incorporating the entire peninsula into the nuclearfree effort, the Agreed Framework avoids specifically targeting North Korea and its suspected plutonium-processing facilities and broadens the spectrum of participants in stopping nuclear proliferation on the peninsula.

\section{U.S. Security Assurances}

Paragraph III also states that "The U.S. will provide formal assurances to the DPRK, against the threat or use of nuclear weapons by the U.S." ${ }^{103}$ Due to a history of hostility it was necessary for the United States to provide assurance to North Korea that the U.S. would not use its own nuclear weapons against the DPRK once the freeze of North Korean facilities had begun. The inclusion of documented security assurances in the Agreed Framework indicates that the U.S. was aware of the intensely real North 
Korean fear of U.S. military capability and the potential for aggression. However, U.S. military policy in the years following the signing of the Agreed Framework ran contrary to the assurances provided in the document. For instance, while the U.S. had removed all nuclear weapons from South Korean soil by the end of 1991 - an effort which began in the late $1970 \mathrm{~s}^{104}$ — the United States still maintained an arsenal of well-equipped nuclear submarines and aircraft in the region, which were easily and rapidly deployable should tensions heighten. $^{105}$

Furthermore, U.S. weapons were showcased annually when they were deployed to Korean skies and waters during the U.S.-ROK joint military exercises, a simulation of combat operations in preparation for war with the DPRK. ${ }^{106}$ The joint exercises, referred to as "Team Spirit" in the early 1990s, have historically been a source of tension in U.S.DPRK relations because the exercises are strongly perceived by the DPRK to be threatening in nature. According to a U.S. official visiting Pyongyang in 1993, “...the Great Leader's voice quivered and his hands shook with anger when he discussed Team Spirit...calling it 'a dress rehearsal for an invasion.",107

As a result of the adversarial tone of the relationship, both countries have maintained a heightened state of readiness on the peninsula since the Korean War Armistice was signed in 1953 and despite the positive advancement of relations spurned by the signing of the Agreed Framework, each side continued to view the other as a serious military threat through the 1990s. According to William Perry, the U.S. military posture in the region was actually strengthened in the years following the signing of the 
Agreed Framework and had become even more robust during the second term of the Clinton Administration. ${ }^{108}$

The U.S. maintained roughly 37,000 U.S. troops on the peninsula until $2004^{109}$ and had similar numbers in Japan, ${ }^{110}$ making it the largest non-NATO (North Atlantic Treaty Organization) U.S. troop presence outside the United States. ${ }^{111}$ However, U.S. troop numbers paled in comparison to North Korea's heavily indoctrinated million-man army. While the United States has the benefit of weapons superiority over the DPRK with aircraft that would leave North Korea "vulnerable to a preemptive strike," North Korea remains a formidable threat because of the sheer number of DPRK soldiers and close proximity to Seoul. ${ }^{112}$ The Four Party Peace Talks

Although a number of border skirmishes have occurred at the DMZ since the end of the Korean War, both sides have been hesitant to engage in full war again, due to the high monetary and mortal cost that is expected. According to William Perry, “...the intensity of combat in another war on the Peninsula would be unparalleled in U.S. experience since the Korean War of 1950-53. It is likely that hundreds of thousands of persons -U.S., ROK, and DPRK - military and civilian - would perish, and millions of refugees would be created." 113

The avoidance of war has been a long-time priority for both countries and the issue came to the forefront of bilateral relations during the Four Party Peace Talks, a series of discussions dedicated to formally ending the war and developing a solid foundation for peace. ${ }^{114}$ Six rounds of official talks occurred between December 1997 
and August 1999 with participation from North Korea, the United States, China and South Korea, the original combatants in the war. ${ }^{115}$ It was the first major multilateral forum regarding North Korean security issues and thereby a groundbreaking event. However, the talks were unsuccessful in putting an end to the armistice. During the last round of discussions in August 1999, differences over which parties should be the signatories of the peace treaty lead to frustration from all sides. ${ }^{116}$ Seoul insisted that a permanent peace treaty be signed between the two Koreas and the United States backed their request. Pyongyang disagreed, insisting that the treaty be signed by the United States and the DPRK. ${ }^{117}$ As a result of the disagreement the next discussion round was left unscheduled and the talks never resumed. ${ }^{118}$

The inconclusive end to the Four Party Peace Talks highlights the complexity of regional relationships and the critical role of security issues in nearly every layer of bilateral and multilateral relations pertaining to the DPRK. Furthermore, the failed talks only amplified building insecurities in North Korea, who had desperately hoped to put an end to the armistice. ${ }^{119}$ In fact, in June 1998, two months prior to the missile launch, Pyongyang had preemptively offered to discontinue missile development if a peace agreement could be reached with the United States that would remove the U.S. military presence on the peninsula. $^{120}$

The Agreed Framework was signed at a time when North Korea was particularly vulnerable. Alliances with both China and the former Soviet Union underwent significant changes in the late 1980s and early 1990s and North Korea had little guarantee that should war break out with the United States that China and Russia would come to its 
aid. ${ }^{121}$ The lessened solidarity with long-time allies may have made the DPRK more susceptible to engagement with the United States, but also equally as fearful and anxious to hedge against its primary adversary in the region.

North Korean fear and suspicion of the United States is a must-know aspect of the U.S.-DPRK relationship. North Korea has long asserted that the United States is its primary enemy and as a result has dedicated large portions of its economy to militaryrelated endeavors. Kim Il Sung once stated "US imperialism is the most ferocious and shameless aggressor and plunderer of modern times and the principal enemy of all progressive peoples of the world." 122 State propagated commentary like this is not uncommon in North Korea. However, while the need for a constant threat is necessary to legitimize the constant mobilization of the population and the overall hardship that the North Korean people endure, the government fear of a potential U.S. attack is genuine. ${ }^{123}$

As a result, deterrence has been a necessary tool for the North Korean regime because of ongoing tensions with South Korea and the United States, which were only exacerbated by the poor results of the Four Party Peace Talks.

"On his return from Pyongyang in September 1999, Perry was asked why North Korea is seeking to develop long-range ballistic missiles. 'I believe their primary reason... is deterrence,' he replied. 'Whom would they be deterring? They would be deterring the United States. We do not think of ourselves as a threat to North Korea, but I truly believe that they consider us a threat to them."

The military aspect of the U.S.-DPRK relationship has been a key factor in bilateral relations between the United States and North Korea for more than a half a century and has had a significant impact on diplomatic and economic relations. With only an armistice in place, the two countries are technically still at war and both have maintained 
an intense state of readiness along the DMZ as the primary mechanism for peace in the bilateral relationship.

\section{South Korean Interests}

As part of the effort to establish a nuclear-free peninsula, paragraph III also required the two Koreas to work together. When it came to the DPRK, the Clinton Administration often factored in the sentiment and judgment of regional allies and sought to coordinate decisions with them. The U.S. pulls South Korean interests into the Agreed Framework by insisting that North Korea "consistently take steps to implement the North-South Joint Declaration on the Denuclearization of the Korean Peninsula." ${ }^{125}$ (Hereinafter referred to as the "1992 Joint Declaration.") Under this agreement, the two Koreas agreed to only use nuclear energy for peaceful purposes and that neither would “test, manufacture, produce, receive, possess, store, deploy or use nuclear weapons;" nor would either establish nuclear reprocessing and uranium enrichment facilities. ${ }^{126}$ In more recent years, the 1992 Joint Declaration has served as a documented guideline for determining North Korea's nuclear violations because the Agreed Framework does not explicitly prohibit uranium enrichment facilities. During the Clinton Administration both Koreas publicly abided by the 1992 Joint Declaration, it was not until the Bush Administration that possible uranium enrichment programs were uncovered in both countries. (See The Bush Administration pgs. 48-57)

Paragraph III also encouraged North Korea to engage in bilateral talks with South Korea, stating that "The DPRK will engage in North-South dialogue, as this agreed framework will help create an atmosphere that promotes such dialogue." ${ }^{127}$ During the 
first term of the Clinton Administration very little progress was made on the fostering of relations between the two Koreas. According to State Department reporting, interKorean relations were still at a standstill in May 1996, due to inertia on both sides. The report states that, "there has been no meaningful North-South dialogue. While the North has clearly sought to avoid governmental talks with the ROK, domestic factors in the South have also been a major obstacle to dialogue."128 There was a shift in inter-Korean relations following the death of Kim Il Sung in 1994. Primarily because South Korean President Kim Young Sam publicized his expectation for the collapse of North Korea after the death was announced and asserted that he would seek to hasten the impending downfall. $^{129}$ As a result, Kim Jong Il made minimal efforts to advance North-South relations while Kim Young Sam was in power. ${ }^{130}$

Inter-Korean relations drastically improved during the latter half of the Clinton Administration, which correlated with the inauguration of Kim Dae Jung as President of the ROK in February 1998. ${ }^{131}$ The Kim Dae Jung presidency ushered in an era of unprecedented ROK engagement with the DPRK, earning Kim a Nobel Peace Prize in 2000. ${ }^{132}$ One of the more notable accomplishments of the Kim Dae Jung presidency was the North-South Summit in 2000, which resulted in a number of forward-leaning outcomes for the two Koreas. Some of the key developments included an agreement to reestablish both road and railway links across the demilitarized zone (DMZ) separating the two Koreas; to reopen the liaison office in Panmujom (a special village at the DMZ which had previously been used as a neutral setting for international discourse); and to allow families who had been separated since the Korean War to visit one another for the 
first time in decades. ${ }^{133}$ During the course of the summit, both sides also expressed an interest in developing joint economic ventures and tourism. ${ }^{134}$

The outcome of positive North-South relations was an increase in inter-Korean trade after the summit and the establishment of the Kaesong Industrial Complex, where textile goods are manufactured through a joint effort. ${ }^{135}$ The Clinton Administration held Kim Dae Jung's policies in high regard, with Secretary of State Albright giving him credit for the opening of positive dialogue with North Korea for the entire region ${ }^{136}$ based on his "Sunshine Policy."137

Unfortunately, although the U.S. considered the South Korean stance when it came to a variety of issues, inter-Korean relations were not weighted as heavily as some of the other points of the Agreed Framework. A declassified document containing talking points for a 1994 meeting between State Department officials and Russian diplomats highlights the secondary nature of North-South relations, stating "Though the Agreed Framework calls on the DPRK to take steps to resume dialogue with the ROK, dialogue is not a precondition for any specific step in the LWR project." ${ }^{\text {"138 }}$ The report goes on to state, "Nevertheless, we believe that successful implementation of the project will require an improvement in North-South relations.","139

The U.S. and ROK were closely aligned in their policy towards North Korea, however, advocating for improved relations with the ROK may have been a strategic move on the part of the United States because U.S. engagement with North Korea proved to be rather expensive for South Korea, who took on the majority of expenses when it came to the implementation of the Agreed Framework and the LWR project in particular. 
Thus, addressing South Korean interests in the document may have also directly served U.S. interests.

Although inter-Korean relations remained a secondary issue, the flourishing North-South relationship is one of many examples of North Korean adherence to the agreements outlined in the Agreed Framework and should not be overlooked when assessing North Korean receptivity to U.S. engagement. 


\section{Paragraph IV: The IAEA and North Korean Cooperation}

The last portion of the Agreed Framework is primarily dedicated to explaining North Korean obligations under the agreement. Paragraph IV states, "Both sides will work together to strengthen the international nuclear non-proliferation regime."140 The wording of this statement is inclusive of the DPRK, in the sense that by putting a stop to its own potential nuclear program North Korea will be participating in an overall strategy to stop the spread of nuclear weapons on a global scale. The United States was also included in this part of the agreement, despite no longer having a need to acquire the technology to produce nuclear weapons.

In accordance with the theme of non-proliferation, paragraph IV required that the DPRK remain a party to the Treaty on the Non-Proliferation of Nuclear Weapons (NPT) and allow implementation of its Safeguards Agreement. ${ }^{141}$ Once the freeze had begun, and the supply agreement for the LWRs was in place, North Korean facilities not subject to the freeze would become subject to inspection by the IAEA, routinely and on an ad hoc basis. ${ }^{142}$ Lastly, the Agreed Framework mandated that North Korea take special precautions for the disposal and storage of spent fuel, a byproduct of the graphitemoderated reactors that was produced prior to the freeze, stating that "The U.S. and DPRK will cooperate in finding a method to store safely the spent fuel from the $5 \mathrm{MW}(\mathrm{E})$ experimental reactor during the construction of the LWR project, and to dispose of the fuel in a safe manner that does not involve reprocessing in the DPRK." 143 


\section{The Freeze and Dismantlement}

North Korea was quick to act upon the primary agreement it made with the United States and froze its graphite-moderated reactors at Yongbyon within one month of the signing of the Agreed Framework under IAEA supervision. ${ }^{144}$ IAEA inspections occurred throughout the Clinton Administration and with compliance from the DPRK. A State Department report noted several consecutive years of North Korean cooperation in December 1996, stating that "Since November 1994, the North's nuclear program has been frozen. This covers the reprocessing plant and small plutonium production reactor at Yongbyon. The North has also halted construction of its two larger and more powerful reactors. The IAEA has been instrumental in implementing the Framework, maintaining a constant presence at Yongbyon since mid-1994."145

During the 1990s, the IAEA was vigilant in its monitoring of Yongbyon, however was prohibited from conducting full-scale inspections of North Korean facilities until the LWR project reached a certain point of completion. The last sub-paragraph of paragraph IV states that, "When a significant portion of the LWR project is completed, but before delivery of key nuclear components, the DPRK will come into full compliance with its Safeguards Agreements with the IAEA (INFCIRC/403), including taking all steps that may be deemed necessary by the IAEA, following consultations with the Agency with regard to verifying the accuracy and completeness of the DPRK's initial report on all nuclear material in the DPRK."146

The IAEA was less than pleased with the "freeze now, confirm later" policy that the U.S. had negotiated with the DPRK and the lengthy confirmation process was a sour 
point for the UN organization from the beginning. According to the IAEA, full implementation of the Agreed Framework would require a minimum of ten years because "Inspection of the two suspect waste storage facilities and full DPRK compliance with its safeguards agreement would not take place until a significant portion of the light water reactor project had been completed." Furthermore, at least five years would elapse before the IAEA could access waste stores or inspect other sites and verify the DPRK's initial report. ${ }^{147}$ Therefore, although the Agreed Framework was successful in putting an immediate freeze on the graphite-moderated reactors at Yongbyon, the details surrounding the usage of the plant prior to the 1994 freeze and North Korean activity at other sites would remain a mystery until the U.S. fulfilled its promises regarding the LWR project.

\section{LWRs in Exchange for the Freeze}

The thorough investigation process required under the Agreed Framework was also of considerable concern to the DPRK. The last sub-paragraph of paragraph IV contains the largest assurance that the agreement asks of North Korea by mandating that the DPRK allow the IAEA to continue inspections after the LWR project has been completed and to be able to investigate facilities that were not previously listed as suspect before. These measures would be extremely invasive for a country as reclusive and esoteric as North Korea. Furthermore, the last paragraph of the Agreed Framework gives the IAEA the power to determine whether or not the DPRK can receive the LWRs in the end, surpassing the bilateral component of the Agreed Framework. 
It is possible that the DPRK was willing to make such a concession because the North Korean regime did not believe that the end result of the Agreed Framework would be completed light-water reactors and therefore they would not have to allow the inspectors the freedom outlined in paragraph IV, but could still reap the benefits of the other aspects of the Framework agreements, such as normalization and heavy oil. On the other hand, it is also possible that North Korea found the LWRs to be of such great value that they were willing to forego the development of any other nuclear-related programs in order to obtain them.

When the Agreed Framework was signed in 1994, North Korea was technologically incapable of producing the key components for LWRs domestically and would have had to import the necessary and very expensive parts to try and assemble a reactor on their own. Furthermore, the promised light-water reactors would be capable of producing exponentially more energy than the graphite-moderated reactors at Yongbyon. It is estimated that if working at full capacity, the reactors at Yongbyon could produce 5 megawatts (5 million watts) of electricity, whereas, two basic LWRs could produce 2,000 megawatts of electricity. ${ }^{148}$ The LWRs would be much more complex than the graphitemoderated reactors that the DPRK was developing in the 1980s and would have provided a notable improvement to domestic energy production in North Korea.

However, the last clause of paragraph IV never became an issue for the DPRK, United States, or IAEA because the LWR project was so far behind schedule that the IAEA was never permitted to conduct a full-scale investigation of North Korean facilities under the terms set forth in the Agreed Framework. 


\section{Quid Pro Quo Progress}

North Korean cooperation was imperative to the success of the Agreed Framework and the key factor in assuaging a major security concern of the United States and its allies. However, it was necessary for the U.S. to meet the DPRK half way if the intended results of the Framework were to be achieved. The chief agreement under the Agreed Framework was the freeze and eventual dismantlement of North Korean facilities in exchange for light-water reactors. However, the Agreed Framework was negotiated with the realization that both parties were highly suspicious of each other and that quid pro quo progress would be necessary for the agreement to work.

The implementation of the Agreed Framework began with formal U.S. assurance that the DPRK would eventually receive LWRs and heavy oil, which was followed by the freeze of the graphite-moderated reactors on the part of North Korea. The next step was for the United States to facilitate the construction of the LWRs and eventually deliver the completed LWRs, which would be followed by the dismantlement of the graphitemoderated reactors at Yongbyon on the part of North Korea and also open the door to full-scale inspections by the IAEA, including confirmation of the DPRK's initial report listing all nuclear facilities in the country.

During the Clinton Administration North Korea made a good-faith effort to comply with the nuclear aspects of the Agreed Framework. In addition to the freeze, North Korea remained a signatory to the NPT and adhered to the agreed upon procedures for the handling of spent fuel, ${ }^{149}$ which was of particular importance because if not disposed of properly, it could be reprocessed and used again if the graphite-moderated 
reactors were ever reactivated. The United States on the other hand, was quick to make assurances, but slow to take the accompanying steps to advance the LWR project. This was unfortunate, because although the Agreed Framework has faced much congressional opposition, the freeze of the graphite-moderated reactors at Yongbyon was a serious matter.

According to the State Department, "A principal goal of the Framework is to enable the IAEA to complete its historical audit of the North's nuclear program to determine empirically how much plutonium the North produced. If the Framework is not implemented successfully, the North would have access to several more bombs-worth of plutonium from the spent reactor fuel now in the cooling pond at Yongbyon." Furthermore, "If fully implemented, the Framework will lead to the complete dismantlement of North Korea's present nuclear capability and to more normal U.S.DPRK relations."151

The Agreed Framework has been criticized for the high cost of North Korean provisions, however, the total cost of implementing the Agreed Framework would have been relatively inexpensive when compared to the annual cost of maintaining U.S. forces in East Asia, which totaled more than $\$ 2.5$ billion a year in South Korea alone, during the late 1990 s. $^{152}$

Under paragraph IV, North Korean benefits become contingent on a global framework. The DPRK was accountable to the United States, to the UN via the NPT, and to South Korea under the 1992 Joint Declaration. The agreement took on a multilateral element for North Korea, whereas the United States was solely accountable 
to the DRPK for the fulfillment of the agreements under the Framework. However, in the end, it was Washington who did not deliver on what was agreed upon, despite steady cooperation from Pyongyang during the Clinton Administration. 


\section{Clinton Conclusion}

The Clinton Administration came to an end without fulfilling all of the agreements made with North Korea under the Agreed Framework, despite steady cooperation from Pyongyang between 1994 and 2001. Of the four primary agreements, the United States was successful in supplying heavy oil to the DPRK, minimally successful in easing economic restrictions on North Korea, behind on the LWR project and unsuccessful in establishing formal diplomatic relations and providing and then upholding security assurances.

The progression of the LWR project in particular, has been a major source of tension between the United States and North Korea. Perhaps the largest oversight that the Framework negotiators had was citing a 2003 target date for the completion of the LWRs, along with what may have been a gross overestimation that Congress would approve funding for the project. Although the Agreed Framework cites a "target" date, ${ }^{153}$ and not a fixed date in the document, in the eyes of North Korea, the inclusion of a timeframe for the completion of the LWRs locked the U.S. into meeting that date in the future.

In a North Korean press release, the DPRK stated that "In the Agreed Framework, the U.S. promised to construct two nuclear light-water reactors with a total generating capacity of approximately 2,000 MW(e) by 2003. In exchange, Pyongyang agreed to stop all its domestic nuclear activities. In a personal letter to General Secretary Kim Jong Il, President Clinton also pledged that he would use "full power" to fulfill the 
commitment. In north Korean values, if one makes a promise to do best for them, it's a moral obligation to keep their own commitment to show their responsibility." "154 Expectations for Collapse

It is possible that in 1994, a 2003 target date seemed like an attainable goal to Framework negotiators. However, U.S. policymakers may have also factored in North Korea's domestic situation during the 1990s and believed that based on North Korean circumstances at the time there was a strong possibility that the 2003 goal would not have to be met. Thus, the Agreed Framework could serve as a quick solution to regional tensions, without long-term commitments.

Throughout the 1990s North Korea encountered unremitting domestic turmoil, to include a series of natural disasters, the deterioration of relationships with communist allies and the first leadership change in DPRK history. Just prior to the signing of the Agreed Framework in 1994, the 45-year reign of Kim Il Sung ended with his unexpected death in July 1994 and power was passed to his son, Kim Jong Il. The situation was so tumultuous that in large numbers, both scholars and U.S. government analysts alike predicted a near and certain collapse for North Korea.

Even by 1998, when the worst of the 1990s was behind the DPRK, expectations for collapse continued to prevail. During a CIA meeting of Korea specialists consisting of a panel of U.S. policymakers, academic experts, analysts from leading foreign policy institutes, the Congressional Research Service, and U.S. intelligence officers, the maximum expectation for regime survival was ten years for the more optimistic on the panel and two years for the less optimistic. ${ }^{155}$ However, "the majority doubted the 
current, deteriorating status could persist for more than five years." ${ }^{156}$ U.S. policymakers — including those on Congressional committees that approved funding for projects pertaining to North Korea — formulated policies based on this information.

The present state of affairs shows that the DPRK has well exceeded these expectations and that the U.S. government was unable to foresee the North Korean ability to survive long-term under such extremely adverse conditions. Therefore, U.S. policy planned during the 1990s was likely based on the expectation of an impending regime collapse and not on a sincere desire to engage North Korea.

It is noteworthy that a 2003 target date was selected as the completion date during Framework negotiations because the date exceeds the two term maximum that President Clinton could serve in office. Thus, even if the project had been on track, the administration would not have been able to account for the last two years of construction and the completion of the project. Thus, Clinton assurances could only go so far. With the end of the administration in 2001 the success and completion of Framework projects was left to the next administration, who could either carry forward, delay or jettison the Agreed Framework and the engagement policies of the Clinton Administration. 


\section{Bush and the Agreed Framework}

When President George W. Bush entered office on January 20, 2001 he began his first term with a full review of Clinton policy towards North Korea. ${ }^{157}$ Although the Bush Administration found the engagement policies of the Clinton era to be unfavorable, the new administration could not find a justifiable excuse to jettison the Agreed Framework because they could not find a more suitable solution to U.S.-DPRK relations. ${ }^{158}$ With no immediate alternative in sight, the Bush leadership begrudgingly continued the policies of the previous administration and continued to implement the agreements in the same fashion as their predecessors.

Meanwhile, North Korea watched with apprehension as a new, more conservative executive leadership took hold of the U.S. government. The DPRK could only speculate with uncertainty whether or not engagement would continue under the new presidency and was especially wary of the Bush take-over following the "Bush v. Gore" controversy at the close of the November 2000 election. ${ }^{159}$ Nevertheless, at the onset of the new administration, the controversial graphite-moderated reactors at Yongbyon remained frozen and IAEA inspections continued with North Korean compliance, a strong indicator of the DPRK desire to see the agreement through. The Agreed Framework remained intact at the beginning of the Bush Administration, however it was only a few more years before things escalated to the breaking point in 2003 and the agreement collapsed.

\section{The Agreements}

Under the auspices of the Agreed Framework, the United States made four primary promises to the DPRK: provisions for light-water reactors (LWRs) and heavy 
oil, the easing of economic restrictions, security assurances and the eventual normalization of diplomatic relations. The United States offered these things to North Korea in exchange for the shutdown and eventual dismantlement of the DPRK's graphite-moderated reactors at Yongbyon.

\section{KEDO Provisions}

The Bush Administration made no further progress than the Clinton Administration in each area of the Agreed Framework, with the exception of the LWRs, where relatively substantial construction developments occurred when compared to the previous administration. Progress on the LWRs can largely be attributed to the timing of the project since there was initially a delay in solidifying a contract for the project and also a late start when it came to the actual commencement of construction during the Clinton Administration. However, during the first term of the Bush Administration construction remained in the preparatory stages and progress on the LWRs continued to lag significantly behind schedule.

In fact, it was not until August 2001 that grading of the construction site was completed, ${ }^{160}$ and not until the summer of 2002 that concrete was first poured at the project site in Kumho, North Korea. ${ }^{161}$ With only a few months left in the year, it had become apparent by the summer of 2002 , that the 2003 target date for fully constructed

and operational LWRs would not be met. ${ }^{162}$ Based on the rate of construction, it would be several years before the two much-desired LWRs could be completed.

KEDO heavy oil shipments continued in 2001 and 2002 and by the end of 2002, North Korea had received 3.52 million metric tons of heavy oil, roughly 500,000 tons a 
year since 1996. ${ }^{163}$ During the Bush Administration heavy oil deliveries remained the most steadfast aspect of U.S. agreements with Pyongyang, much like the previous administration.

Economic Barriers and Diplomatic Normalization

The standstill on both economic and diplomatic normalization continued. No further steps were taken to relax economic restrictions on the DPRK and although liaison offices were still being considered by both parties, there were no moves forward on the issue and formal diplomatic offices were never established. ${ }^{164}$

U.S. Security Assurances, The "Axis of Evil," and 9/11

Clinton policies were upheld at the onset of the Bush Administration, which was demonstrated by the continued delivery of heavy oil, construction of the LWRs and similarity in approaches to economic and diplomatic relations. However, the status quo changed a year into the new administration when President Bush named the DPRK as a top adversary during his State of the Union Address in January 2002. ${ }^{165}$ The U.S.-DPRK relationship began to rapidly deteriorate afterwards. President Bush's reference to North Korea as part of an "axis of evil"166 completely uprooted the security assurances that were established during the Clinton Administration, nullifying the Letter of Assurance delivered to Kim Jong Il from President Clinton, ${ }^{167}$ in addition to sending the DPRK into a state of panic. Whether intentional or not, the State of the Union Address changed the tone of a transitioning relationship from uncertain to menacing. The speech was a pivotal point in U.S.-DPRK relations. 
The rhetoric in the President's speech was largely in response to the terrorist attacks that occurred on September 11, 2001, ${ }^{168}$ just months prior to the State of the Union Address. The attacks changed the scheme of American security interests as the everyday American became more conscientious of outside threats and the burgeoning intensity of anti-American sentiment. ${ }^{169}$ As tensions between the United States and the Middle East grew, with a strong domestic backing in the U.S., North Korea watched fearfully as the situation developed, unsure whether or not the U.S. was beginning a military campaign against all of its noted adversaries. ${ }^{170}$ The DPRK could not be sure of U.S. intentions, but developing wars in Iraq and Afghanistan ${ }^{171}$ seemed foreboding to a country that was listed as one of three in President Bush's "Axis of Evil" speech. The speech revealed the underlying tensions already present at the onset of the Bush Administration and the U.S.-DPRK relationship deteriorated even further in the years following the speech.

\section{Uranium Enrichment Facilities in North Korea}

During the early Bush Administration, North Korea continued the freeze of its graphite-moderated reactors at Yongbyon and remained in compliance with IAEA standards for the frozen facilities. However, outside of the illustrious Yongbyon facility, the DPRK did not fully adhere to the requirements of the Non-Proliferation Treaty or the 1992 Joint Declaration and thereby violated the Agreed Framework. It is uncertain when the DPRK began developing its uranium enrichment program and whether or not the amount of enriched uranium qualified as weapons-grade. However, the United States 
accused the DPRK of developing a nuclear weapons program in October 2002, ${ }^{172}$ although there was still uncertainty surrounding key details of the program.

North Korea's uranium enrichment program quickly gained global media attention and a series of events followed the confrontation that lead to the collapse of the Agreed Framework. According to KEDO, in response to reports of the suspected uranium enrichment facilities, KEDO’s Executive Board decided to suspend heavy oil shipments to the DPRK beginning in December 2002. ${ }^{173}$ Subsequently, North Korea expelled IAEA inspectors from Yongbyon at the end of December 2002; announced its withdrawal from the NPT on January 10, 2003; and resumed operations at Yongbyon shortly thereafter, ending an eight year freeze that began in November $1994 .{ }^{174}$

Furthermore, in mid-2003, North Korea announced that it had completed the reprocessing of spent nuclear fuel rods, to extract weapons-grade plutonium, and was developing a "nuclear deterrent," according to the CIA. ${ }^{175}$

Note that it was only after KEDO took punitive measures against North Korea, that the DPRK in turn staged its own response. Prior to KEDO actions, North Korea had only responded verbally to deny the use of the suspected program for nefarious purposes, but had taken no nuclear-related actions in response to the confrontation with the United States and IAEA.

KEDO took further action after North Korea ended the freeze on the graphitemoderated reactors and suspended the LWR project on December 1, 2003. At the time, construction at the LWR site was approximately $34.5 \%$ complete, according to KEDO. ${ }^{176}$ KEDO's Executive Board agreed to extend the suspension for an additional year in 
November $2004^{177}$ and began serious discussions regarding the termination of the LWR project in November 2005. ${ }^{178}$ By January 2006 KEDO had withdrawn all workers from the LWR construction site and in May of that year the Executive Board moved to terminate the LWR project entirely, claiming that the DPRK had failed to perform the steps required in the KEDO-DPRK supply agreement. ${ }^{179}$

\section{Sanctions and International Condemnation}

In response to the discovery of the possible uranium enrichment facilities, the Bush Administration enacted a number of unilateral sanctions against North Korea under The North Korea Democracy Act of 2003 (S. 145). The updated sanctions prohibited assistance to North Korea under the Agreed Framework and via KEDO; limited "the entry into force of any nuclear cooperation agreement between the two countries, including the transfer or trade of materials;" and also required that sanctions be "less restrictive" than the sanctions in effect against North Korea prior to September 17, 1999, that were reduced in response to the North Korean missile launch. ${ }^{180}$

The $108^{\text {th }}$ Congress also amended House Joint Resolution 2 (H.J. Res. 2) introduced by Senator John McCain — which expressed the Senate's recommended approach on North Korea. The amendment encouraged the United States and its allies to take measures to prepare for the "worst scenario," because of the "serious threat" that North Korea posed to the region. In addition, the amendment condemned North Korea for not abiding by the terms of the Agreed Framework and called for increased Radio Free Asia broadcasts to North Korea. ${ }^{181}$ 
In April 2004, the UN also adopted Security Council Resolution 1540, condemning North Korea for its nuclear-related actions and requesting that states refrain from helping North Korea to develop, acquire or transport nuclear, chemical or biological weapons. $^{182}$

\section{South Korea's Nuclear Experiments}

North Korea's uranium enrichment program indirectly violated the Agreed Framework, which states that "The DPRK will consistently take steps to implement the North-South Joint Declaration on the Denuclearization of the Korean Peninsula." "183 Although there is no mention of uranium in the text of the Agreed Framework (which addresses the suspected plutonium-processing facilities at Yongbyon), under the 1992 Joint Declaration, both Koreas agreed that "The South and the North shall not possess nuclear reprocessing and uranium enrichment facilities." ${ }^{184}$ A point of interest because at the time of the uncovering of a possible uranium enrichment facility in North Korea, South Korea was also in violation of the Joint Declaration.

The ROK uranium enrichment program was not discovered until 2004; however South Korea conducted nuclear experiments in early 2000, and in the immediate aftermath refused IAEA inspections for several years. ${ }^{185}$ When the IAEA was finally permitted to visit the facility in question in early 2004, the South Koreans would not allow the IAEA to take environmental samples from the site. ${ }^{186}$ The suspicious behavior, which was in direct violation of the NPT and the 1992 Joint Declaration, ${ }^{187}$ was ignored by the United States and the IAEA. When confronted in 2004, the South Korean government claimed that the testing took place without government approval. ${ }^{188}$ 
However, the 2004 discovery revealed a history of concealed experiments. According to the IAEA "On a number of occasions, starting in 1982 and continuing until 2000, the ROK conducted experiments and activities involving uranium conversion, uranium enrichment and plutonium separation, which it failed to report to the Agency in accordance with its obligations under its Safeguards Agreement."189 However, despite the shocking nature of the unreported experiments, no punitive measures were taken by the UN. In addition, although the third paragraph of the Agreed Framework states "Both sides will work together for peace and security on a nuclear-free Korean Peninsula,"190 the U.S.-ROK alliance was generally unaffected and no actions were taken against South Korea by the United States. The double-standard is notable, as the discovery of North Korea's uranium enrichment program in 2002 resulted in unilateral sanctions and other punitive measures. However, there was essentially no backlash against South Korea for its long-term experiments. 


\section{Bush Conclusion}

Although the Bush Administration did not immediately abandon the Agreed Framework, progress on the agreement was overwhelmed by tensions from the start. It was reasonable for the new administration to be apprehensive of the Agreed Framework initially, as the United States had made very lofty agreements with a country that many politicians felt had given very little assurance that it could be trusted in the past.

However, one could argue that the Bush Administration was never completely receptive towards engagement with North Korea and was searching for an opportune moment to put an end to the agreement early on. The contrast between the U.S. reaction to North Korea's uranium enrichment program and South Korea's varied and long-term nuclear experimentation reveals how inflexible the administration was when it came to North Korean progress on the Framework.

However, had the Bush Administration carried forward the Agreed Framework could engagement with North Korea have worked? While both countries were a party to the agreement, North Korea's suspected plutonium-processing facilities remained frozen. Many criticize the Bush Administration for heightening tensions and not preventing what the U.S. was concerned about in 1993, the plutonium-processing facilities, which were restarted while Bush was in office. In that regard, the Agreed Framework, although somewhat costly had accomplished the first part of what it set out to do under the Clinton Administration and that was to freeze the facilities. Had Bush continued down the Clinton path perhaps the Yongbyon facility would be dismantled or close to dismantlement by now. 
However, on the other hand the Clinton Administration's inability to follow through on the most tangible aspects of the Agreed Framework contributed to the deterioration of relations between the two countries during the Bush Administration. It is possible that the DPRK had given up on the Agreed Framework at the end of the Clinton Administration. In an assessment provided to Congress in November 2002, the CIA claimed that the DPRK had begun constructing a centrifuge-based uranium enrichment facility two years prior. ${ }^{191}$ Interestingly enough, the CIA estimate would indicate that the DPRK would have seriously begun uranium enrichment efforts around the close of the 2000 election, marking the end of the Clinton Administration and the start of a new presidency. The unsuccessful implementation of several aspects of the Agreed Framework on the U.S. side of things possibly played a part in the development of uranium research in the DPRK. The threat of nuclear weapons production could be used as leverage to obtain Framework provisions that had not come through and to serve as a deterrent to the less engaging and openly hostile Bush Administration. 


\section{The Collapse of the Agreed Framework}

"North Korea is the world's most accomplished serial violator of international agreements, beginning with the Korean War Armistice Agreement it signed in 1953 and including every other significant subsequent DPRK commitment. Most pertinent here, these breaches include repeated promises to give up its nuclear capabilities, beginning with the 1992 Joint North-South Declaration and the ill-fated 1994 Agreed Framework." (John Bolton, October $2008)^{192}$

In February 2003, the Democratic People's Republic of Korea (DPRK) restarted its plutonium-processing facilities at Yongbyon, putting an end to the "nuclear" freeze that had lasted nearly a decade. ${ }^{193}$ This event has been termed the "collapse" or the "breakdown" of the 1994 Agreed Framework, what was perhaps the most landmark agreement between the United States and North Korea since the signing of the Korean War Armistice Agreement several decades before.

The Agreed Framework provided an optimistic turn of events for U.S.-DPRK relations in the 1990s by avoiding what was predicted to be a second bloody and costly war on the peninsula. Furthermore, it marked the commencement of U.S. engagement policy with North Korea and laid the foundation for U.S.-DPRK relations during two presidential administrations and the Kim Jong Il leadership. ${ }^{194}$ Its collapse in 2003 was no small matter.

Critics of engagement with North Korea have been quick to cite the collapse of the Agreed Framework as simply a byproduct of engaging a rogue and untrustworthy state such as North Korea, or as John Bolton put it, “the world's most accomplished serial violator of international agreements." ${ }^{\prime 195}$ However, a review of the Agreed Framework and its implementation reveals that the breakdown of the Agreed Framework was a lengthy and complex process in which both parties contributed and not simply a matter of North Korean deceitfulness. 
According to Victor Cha, engagement is "a discrete type of security response to a threatening power, actively seeking to transform the relationship into a non-adversarial one and to change the threatening state's behaviour and goals in the process."196 It is apparent from North Korean actions over the course of eight years that Pyongyang was receptive to U.S. engagement and had for some time changed both its behavior and goals regarding nuclear weapons development. North Korean cooperation at Yongbyon was well-documented during both administrations and included the freeze of the graphitemoderated reactors, down to the small nuances of the agreement such as the handling of spent fuel. North Korea consistently upheld the primary agreement it made with the United States to freeze the graphite-moderated reactors and related facilities at Yongbyon, even though the Agreed Framework was not being implemented as promised by the United States.

Furthermore, even after President Bush laid the groundwork for tensions with his “axis of evil” speech in early 2002, North Korea did not respond with provocations. Pyongyang patiently tried to see the agreement through and it was not until KEDO stopped heavy oil deliveries to the DPRK that North Korea restarted the reactors at Yongbyon. After being short-changed for nearly a decade when it came to U.S. provisions, diplomacy, economic relief and security assurances, the cessation of heavy oil — what had been the most consistent of the U.S. agreements - made the Agreed Framework obsolete in the eyes of North Korea. 


\section{The Outcome}

With the restarting of the suspected plutonium-processing facilities at Yongbyon and the cessation of the LWR project and heavy oil shipments, U.S.-DPRK relations had reached the breaking point and continued down a rocky path for several years afterward. However, North Korea's threat of developing a "nuclear deterrent" brought the U.S. back to the negotiating table and the situation in 1994 replayed itself. North Korea and the United States engaged in multilateral talks involving China, Japan, Russia and South Korea, beginning in August 2003, with the aim of resolving the stalemate over North Korea's nuclear programs. The multilateral discussions, known as the Six-Party Talks continued through 2007 when North Korea agreed to sign two agreements on

denuclearization and shutdown Yongbyon once more in exchange for U.S. provisions. ${ }^{197}$ 


\section{Conclusion}

From the onset of the Agreed Framework there have been skeptics of engaging North Korea and the likelihood of success has been highly debated. Some of the more vocal critics of engagement have deemed it to be an outright failure, among them former U.S. Ambassador to the UN, John Bolton. However, even supporters of engagement can at times find it difficult to defend engaging North Korea.

In a 2007 edition of the National Inquirer, John Bolton and James A. Kelly, the former Assistant Secretary of State for East Asian and Pacific Affairs, debated the merits of diplomacy with North Korea. Although Kelly was a proponent of engagement with North Korea and also one of the front men for the Six-Party Peace Talks, he gave a tepid defense for maintaining diplomacy with North Korea. During the debate Kelly made the following statement, "The upshot is that diplomacy has been unsuccessful and the sixparty process has not worked. But neither have attempts at pressure been fruitful. The truth is that any new diplomatic negotiation, absent some kind of internal change in North Korea, is unlikely to be successful in disarming Pyongyang of its nuclear weapons."198 Needless to say, Bolton was delighted with this very drab statement from the Assistant Secretary of State for East Asian and Pacific Affairs.

By the time of the 2007 debate, both Kelly and Bolton had witnessed thirteen years of U.S.-DPRK relations since the signing of the Agreed Framework in 1994. After witnessing nearly a decade and a half of attempted engagement with North Korea, was it fair for Kelly and Bolton to concur that "diplomacy" or engagement with North Korea had been unsuccessful? It appears they may have ignored the other very important 
variable in the nuclear negotiations, the United States. Kelly's statement that successful diplomacy requires internal change in North Korea implies that the United States has sincerely attempted to engage North Korea, but that things haven't worked out because of North Korea's underhanded way of conducting foreign policy.

This is simply untrue. North Korea violated the Agreed Framework by partaking in uranium enrichment experiments. However, while both parties contributed to the breakdown of the Agreed Framework, the fact that the U.S. has either reneged upon or eluded many of the agreements made under the Agreed Framework should not be ignored when assessing the success of engagement with North Korea.

Furthermore, I argue that the success or failure of U.S. engagement policy with North Korea, as it pertains to the Agreed Framework cannot be ascertained because the U.S. has yet to sincerely attempt to engage North Korea. Unfortunately the window for giving engagement a chance may have passed, as U.S.-DPRK relations have already been damaged significantly, as a result of the half-hearted engagement attempts of the Clinton and Bush Administrations.

It would be reasonable for any avid observer of western news to conclude that engagement with North Korea is an unavailing aspiration. However, the dismal outcome of engagement with North Korea is not solely a byproduct of engaging a "rogue" and untrustworthy state, but has also proved futile in the presence of the hawkish elements of the U.S. government, which have obstructed the engagement process on numerous occasions. Thus, it is inaccurate to call "engagement" or "diplomacy" with North Korea a failure, because the U.S. has yet to fully carry through its own engagement policies with 
North Korea, nor has the U.S. been able to maintain clear and consistent policy goals towards North Korea in the last fifteen years.

\footnotetext{
${ }^{1}$ Becker, Jasper. Rogue Regime: Kim Jong Il and the Looming Threat of North Korea. New York: Oxford University Press, Inc., 2005, ix. (Hereinafter cited as Becker, Rogue Regime.) "North Korea is the quintessential rogue regime, and its end may only come after a terrifying war. The term 'rogue state' is reserved only for the most incorrigible in the international system. Rogue states engage in rash behavior, subjugate their populations, are hostile to the ideologies and interests of the free world, and, most troublingly, breach established international rules in many areas: diplomacy, trade, terrorism, human rights, dangerous weapons, narcotics, and so on. In particular these states' active pursuit of weapons of mass destruction qualifies them for the label 'rogue,' a certificate of dangerous insanity in the diplomatic world."
}

2 "Cheney Alerts Asia to Korean Danger." The Times. 11/23/1991. $<$ http://www.thetimes.co.uk/tto/news/>.

"NORTH AND SOUTH KOREA; USA attempting to give North Korea 'a public image as a dangerous state'." BBC Summary of World Broadcasts. 9/20/1991.

3 "Text of President Bush's 2002 State of the Union Address." The Washington Post. 1/29/2002. $<$ http://www.washingtonpost.com/wp-srv/onpolitics/transcripts/sou012902.htm>. (Hereinafter cited as Bush, State of the Union Address.)

${ }^{4}$ U.S.-DPRK hostility is deeply rooted in history.

Becker, Rogue Regime, 171. One of the initial encounters that Korea had with the United States ended in an on-shore battle with the seamen of the S.S. General Sherman.

Eckert, Carter. Korea Old and New: A History. Cambridge \& London: Harvard University Press, 1990, 238. The United States signed the Taft-Katsura agreement with Japan in 1905, which opened the doorway for the occupation of Korea in the early $20^{\text {th }}$ century.

Martin, Bradley K. Under the Loving Care of the Fatherly Leader. New York: St. Martin's Press, 2004, 85. 
The United States also blanket-bombed North Korea during the Korean War, resulting in the death of millions of civilians. (Hereinafter cited as Martin, Under the Loving Care.)

Martin, Under the Loving Care, 128. On the DPRK side of things, the North Koreans imprisoned U.S. navy personnel aboard the U.S.S Pueblo and charged them with spying, after finding the ship in North Korean waters in 1968.

Martin, Under the Loving Care, 138. There was also the axe incident in 1976, when a North Korean soldier killed several American soldiers who were trimming trees at the DMZ. There have also been several terrorist acts and kidnappings involving the Republic of Korea.

5 “Official: Engagement with North Korea Yielding Results." The Associated Press. 3/16/2000. $<$ http://www.ap.org/>. For example, in an Associated Press article regarding North Korea, the first sentence states, "A top State Department official said Thursday the United States continues to take 'very slow, small steps forward' in its quest to bring stability to the Korean Peninsula through engagement with North Korea." The word "engagement," is mentioned several times throughout the article, but an explanation of the term does not appear anywhere in the text. Throughout my research, I have found the omission of a definition of "engagement" common in both news and academic sources.

${ }^{6}$ Engagement is a form of diplomacy and often "engagement" is not referred to directly, but the word "diplomacy" is used instead. Please note that it is sometimes used interchangeably with "diplomacy" in news and academia.

${ }^{7}$ Cha, Victor. "Engaging North Korea Credibly." Survival, 42:1 Summer 2002, 136-155.

${ }^{8}$ Sigal, Leon V. Disarming Strangers: Nuclear Diplomacy with North Korea. Princeton, New Jersey: Princeton University Press, 1998. (Hereinafter cited as Sigal, Disarming Strangers.)

${ }^{9}$ Becker, Rogue Regime.

${ }^{10}$ Eberstadt, Nicholas. The North Korean Economy: Between Crisis \& Catastrophe. New Brunswick: Transaction Publishers, 2007. (Hereinafter cited as Eberstadt, North Korean Economy.)

${ }^{11}$ Armstrong, Charles K. The Koreas. New York: Routledge Taylor \& Francis Group, 2007, 58. "From the mid-1950s to the 1990s, juche, often translated as 'self-reliance,' was a ubiquitous slogan in the DPRK, associated with cultural independence, economic self-sufficiency, national sovereignty, and the defense of the regime and its leaders. More than a political or economic principle, juche was supposed to encapsulate a general outlook on the world, a way of life. Above all, juche expressed a highly nationalistic, "Korea-centric" worldview." ..."But by continuing a policy of self-reliance for decades, North Korea has become increasingly anomalous in a world characterized by deepening ties of communication and interdependence. The economic implosion of North Korea in the 1990s seemed like the inevitable result of juche carried to its logical and self-destructive extreme. Yet juche, although somewhat less emphasized since the 1990s, still occupies a central place in the official North Korean lexicon."

${ }^{12}$ Harrison, Selig S. “Did North Korea Cheat?” Foreign Affairs, January/February 2005. <http://www.foreignaffairs.com/articles/60431/selig-s-harrison/did-north-korea-cheat>. (Hereinafter cited as Harrison, Did North Korea Cheat?)

${ }^{13}$ Oberdorfer, Don. The Two Koreas: A Contemporary History. United States: Basic Books, 2001 (new 
edition), 250. (Hereinafter cited as Oberdorfer, The Two Koreas.)

${ }^{14}$ Oberdorfer, The Two Koreas, 251.

${ }^{15}$ Oberdorfer, The Two Koreas, 255.

${ }^{16}$ Oberdorfer, The Two Koreas, 256.

${ }^{17}$ Laney, James T. \& Shaplen, James T. "How to Deal With North Korea." Foreign Affairs, March/April 2003. < http://www.foreignaffairs.com/articles/58810/james-t-laney-and-jason-tshaplen/how-to-deal-with-north-korea>. (Hereinafter cited as Laney \& Shaplen, How to Deal.) "In 1994, the United States was on the edge of war with North Korea. Washington had beefed up its forces in the theater, installed Patriot missile batteries in the South, and was reviewing detailed war plans. The White House had even begun to consider the evacuation of American citizens. The 1994 Agreed Framework, although deeply flawed, represented the best deal available at a far from ideal time. It remained so for several years. And although it has been disappointing on many levels, the agreement has not been useless."

${ }^{18}$ Oberdorfer, The Two Koreas, 317-336.

${ }^{19}$ Oberdorfer, The Two Koreas, 339-345.

${ }^{20}$ Harrison, Selig S. "Time to Leave Korea?” Foreign Affairs, March/April 2001. <http://www.foreignaffairs.com/articles/56847/selig-s-harrison/time-to-leave-korea\#>. (Hereinafter cited as Harrison, Time to Leave.) "The signatories to the 1953 Armistice were North Korean and Chinese generals and U.S. General Mark W. Clark, representing the United Nations command, which provided the multilateral umbrella for U.S. intervention. Syngman Rhee, then president of South Korea, had wanted to continue fighting, and thus the South refused to sign."

Armistice Agreement for the Restoration of the South Korean State. 27 July 1953.

$<$ http://www.ourdocuments.gov/doc.php?doc=85\&page=transcript>. (Also known as the "Korean War Armistice Agreement.")

${ }^{21}$ International Atomic Energy Agency. Agreed Framework of 21 October 1994 Between the United States of America and the Democratic People's Republic of Korea. 2 November 1994. <http://www.gwu.edu/ nsarchiv/NSAEBB/NSAEBB87/nk17.pdf> (Hereinafter cited as Agreed Framework.)

${ }^{22}$ Oberdorfer, The Two Koreas, 289-90. "Light-water reactors, originally so named to distinguish them from reactors using deuterium oxide, or heavy water, rely on ordinary water to moderate the nuclear reaction that produces energy."

23 “Text of President Clinton's Letter to Kim Jong II." 20 October 1994. Sigal, Leon V. Disarming Strangers: Nuclear Diplomacy with North Korea. Princeton, New Jersey: Princeton University Press, 1998, appendix II, 264. (Hereinafter cited as Clinton, Letter to Kim Jong II.)

${ }^{24}$ Agreed Framework. 
${ }^{25}$ In this thesis, the term "graphite-moderated reactors," will be used interchangeably with "plutoniumprocessing facilities."

${ }^{26}$ United Nations, International Atomic Energy Agency. Fact Sheet on DPRK Nuclear Safeguards. <http://www.iaea.org/newscenter/focus/iaeadprk/fact_sheet_may2003.shtml>. According to the IAEA, North Korea announced its decision to withdraw from the NPT in March 1993, but suspended the decision in June 1993. However, as tensions between the United States, IAEA, and North Korea developed, the DPRK became increasingly uncooperative with IAEA inspections and would not comply with IAEA safeguards procedures. Prior to the Jimmy Carter visit, North Korea withdrew from the IAEA entirely. However, with the signing of the Agreed Framework, North Korea agreed to comply with UN and IAEA measures once more.

${ }^{27}$ Joint Declaration of the Denuclearization of the Korean Peninsula. <http://www.state.gov/t/ac/rls/or/2004/31011.htm>. (Hereinafter cited 1992 Joint Declaration.)

${ }^{28}$ Agreed Framework.

${ }^{29}$ The White House. William J. Clinton. 2009. Available at <http://www.whitehouse.gov/about/presidents/williamjclinton>.

30 "Interview William Perry (transcript)." Gaviria, Marcela, dir. Kim's Nuclear Gamble. Airdate 10 April 2003. Frontline, Public Broadcasting System.

<http://www.pbs.org/wgbh/pages/frontline/shows/kim/interviews/perle.html>. "There was unhappiness in the Congress of the United States with the Agreed Framework. Let me remind you, the Agreed Framework was not a treaty. It was an agreement between governments, and because it was not a treaty, it did not require verification by the Senate. Many of the congressmen -- many senators in particular -were unhappy that this was not made a treaty, so they'd have an opportunity to either ratify it or reject it."

${ }^{31}$ Laney \& Shaplen, How to Deal. "Indeed, it averted a potentially catastrophic situation. Instead of war (which the U.S. military commander in South Korea, General Gary Luck, estimated would have killed a million people, including 80,000 to 100,000 Americans), Northeast Asia has experienced eight years of stability. This has had vast implications beyond security."

${ }^{32}$ Agreed Framework, paragraph I.

${ }^{33}$ Agreed Framework, paragraph I subparagraph III.

34 "Transcript" (full). Gaviria, Marcela, dir. Kim's Nuclear Gamble. Airdate 10 April 2003. Frontline, Public Broadcasting System. <http://www.pbs.org/wgbh/pages/frontline/shows/kim/etc/script.html>. Interview with John McCain.

${ }^{35}$ Agreed Framework, paragraph I. The letter receives mention in the Agreed Framework as "the October 20, 1994 letter of assurance from the U.S. President."

${ }^{36}$ Clinton, Letter to Kim Jong II.

${ }^{37}$ Agreed Framework, paragraph I subparagraph I. This detail receives an initial mention in President Clinton's October $20^{\text {th }}$ Letter of Assurance. 
Korean Peninsula Energy Development Organization. Agreement on Supply of a Light-Water reactor Project to the Democratic People's Republic of Korea Between the Korean Peninsula Energy Development Organization and the Government of the Democratic People's Republic of Korea. 15 December 1995. $<$ http://www.kedo.org/pdfs/SupplyAgreement.pdf>. (Hereinafter cited as KEDO Supply Agreement.)

${ }^{38}$ Agreed Framework, paragraph I subparagraph II.

${ }^{39}$ Sigal, Disarming Strangers, 9. "The total price of replacing the nuclear reactors, plus the supply of oil, is reckoned to be $\$ 5$ billion, almost all of it borne by South Korea, Japan, and others."

${ }^{40}$ Agreed Framework, paragraph I subparagraph I.

41 “About Us: Our History." KEDO. 1999-2012. <http://www.kedo.org/au_history.asp>. (Hereinafter cited as KEDO, History.)

${ }^{42}$ Korean Peninsula Energy Development Organization. Agreement on the Establishment of the Korean Peninsula Energy Development Organization. 9 March 1995.

<http://www.kedo.org/pdfs/EstablishmentKEDO.pdf>.

Agreed Framework, paragraph I subparagraph I.

${ }^{43}$ Agreed Framework, paragraph I subparagraph I.

${ }^{44}$ KEDO Supply Agreement.

${ }^{45}$ Korean Peninsula Energy Development Organization. 2001 Annual Report. 31 December 2001. <http://www.kedo.org/pdfs/KEDO_AR_2001.pdf>. (Hereinafter cited as KEDO, 2001 Annual Report.)

Eberstadt, North Korean Economy, 118-9.

${ }^{46}$ KEDO, 2001 Annual Report.

"Stalemated LWR Project to Prompt Pyongyang to Restart N-Program." The People's Korea. 5/13/1998. <http://www1.korea-np.co.jp/pk/042nd_issue/98051302.htm> (Hereinafter cited as The People's Korea, Stalemated LWR Project.) According to a DPRK press release in 1998, "The U.S. side has not set forth the timetable for heavy oil supply this year and is not supplying heavy oil to the DPRK in time."

${ }^{47}$ KEDO, 2001 Annual Report.

48 "About Us: Member Nations." KEDO. 1999-2012. < http://www.kedo.org/au_members.asp>. Member nations included: Japan, South Korea, U.S.A., European Union, New Zealand, Australia, Canada, Indonesia, Chile, Argentina, Poland, Czech Republic and Uzbekistan. Member nations were added between 1995 and 2000. The European Union became an Executive Board member in 1997.

U.S. Department of State. State Department Briefing Paper, Subject: US-Japan-Korea Trilaterals. ca. May 1996. Available at <http://www.gwu.edu/ nsarchiv/NSAEBB/NSAEBB164/EBB\%20Doc\%2011.pdf>. (Hereinafter cited as US-Japan-Korea Trilaterals.) "Efforts by the U.S., ROK, and Japan to garner broad 
international financial and political support for KEDO and its activities have resulted in contributions from 19 countries and the additional membership of seven countries: Australia, Canada, New Zealand, Finland, Indonesia, France, and Argentina."

${ }^{49}$ US-Japan-Korea Trilaterals.

${ }^{50}$ KEDO, 2001 Annual Report.

${ }^{51}$ US-Japan-Korea Trilaterals.

${ }^{52}$ Ahn, Byung-joon. “The Man Who Would Be Kim?” Foreign Affairs, November/December 1994. <http://www.foreignaffairs.com/articles/50552/byung-joon-ahn/the-man-who-would-be-kim>.

In a 1994 Foreign Affairs journal article, Byung-joon Ahn stated that, “...it is the South that has committed to financing 70 percent of the cost of the light-water reactors through an international consortium, the Korea Energy Development Organization, to be launched under Washington's auspices."

${ }^{53}$ Manyin, Mark E. Foreign Assistance to North Korea. Congressional Research Service. 26 May 2005. <http://www.au.af.mil/au/awc/awcgate/crs/rl31785.pdf>. (Hereinafter cited as CRS, Foreign Assistance to North Korea.)

${ }^{54}$ CRS, Foreign Assistance to North Korea.

${ }^{55}$ CRS, Foreign Assistance to North Korea.

56 “Interview Robert Galluci (transcript).” Gaviria, Marcela, dir. Kim's Nuclear Gamble. Airdate 10 April 2003. Frontline, Public Broadcasting System.

<http://www.pbs.org/wgbh/pages/frontline/shows/kim/interviews/gallucci.html>.

57 "Interview Stephen Bosworth (transcript)." Gaviria, Marcela, dir. Kim's Nuclear Gamble. Airdate 10 April 2003. Frontline, Public Broadcasting System.

<http://www.pbs.org/wgbh/pages/frontline/shows/kim/interviews/bosworth.html>.

${ }^{58}$ Sigal, Disarming Strangers, 191.

${ }^{59}$ CRS, Foreign Assistance to North Korea.

60 “Light Water Reactor Project: Turnkey Contract." KEDO. 1999-2012.

<http://www.kedo.org/Iwr_turnkey_contract.asp>. (Hereinafter cited as KEDO, LWR Turnkey Contract.)

${ }^{61}$ KEDO, LWR Turnkey Contract.

"Rummy's North Korea Connection What did Donald Rumsfeld know about ABB's deal to build nuclear reactors there? And why won't he talk about it?." CNN Money. 5/12/2003.

<http://money.cnn.com/magazines/fortune/fortune_archive/2003/05/12/342316/>.

62 KEDO, 2001 Annual Report.

63 "LWR provision is U.S. obligation = DPRK Foreign Ministry spokesman." Korean Central News Agency of DPRK. 3/6/1998. <http://www.kcna.co.jp/item/1998/9803/new03/06.htm\#8>. 
${ }^{64}$ Agreed Framework, paragraph II.

${ }^{65}$ Rennack, Dianne E. North Korea: Economic Sanctions. Congressional Research Service. 24 January 2003. <http://www.au.af.mil/au/awc/awcgate/crs/rl31696.pdf>. (Hereinafter cited as CRS, North Korea: Economic Sanctions.)

${ }^{66}$ CRS, North Korea: Economic Sanctions.

${ }^{67}$ CRS, Foreign Assistance to North Korea.

${ }^{68}$ CRS, North Korea: Economic Sanctions. U.S. sanctions are often amended or revised and have varied in strictness over the years.

${ }^{69}$ CRS, Foreign Assistance to North Korea.

${ }^{70} \mathrm{CRS}$, Foreign Assistance to North Korea.

${ }^{71}$ Agreed Framework, paragraph II subparagraph I.

72 "North Korea to Lift Ban on Trade Ties with U.S." The New York Times. 1/09/1995. <http://www.nytimes.com/1995/01/09/world/world-news-briefs-north-korea-to-lift-banon-trade-ties-with-us.html>. The changes would allow American ships entry into North Korean ports and the establishment of telecommunications links between the two countries.

73 “Clinton Administration Eases N. Korea Trade Sanctions: Diplomacy: Direct phone calls, credit-card transactions are among concessions called for by nuclear treaty." Los Angeles Times. 1/21/1995. <http://articles.latimes.com/1995-01-21/news/mn-22738_1_north-korea>. (Hereinafter cited as Los Angeles Times, Clinton Administration Eases N. Korea Trade Sanctions.)

${ }^{74}$ Sigal, Disarming Strangers, 197-8.

Los Angeles Times, Clinton Administration Eases N. Korea Trade Sanctions. Each country would be permitted to open news offices in the others capital cities also.

${ }^{75}$ Los Angeles Times, Clinton Administration Eases N. Korea Trade Sanctions.

${ }^{76}$ U.S. Department of State. State Department Talking Points [in re North Korean economic situation and food aid]. ca. May 1996. Available at

<http://www.gwu.edu/ nsarchiv/NSAEBB/NSAEBB205/Document\%20No\%206.pdf>. (Hereinafter cited as Department of State, Talking Points [the Agreed Framework.)

${ }^{77}$ Oberdorfer, The Two Koreas, 339-345.

${ }^{78}$ Hughes, Christopher W. Japan's Economic Power and Security: Japan and North Korea. London \& New York: Routledge, 1999, 65-66. (Hereinafter cited as Hughes, Economic Power and Security.)

${ }^{79}$ Hughes, Economic Power and Security. The Japanese reaction to the rocket launch was quick and severe. Japan officially announced that normalization talks would not be convening 
in the near future, that food aid to North Korea would come to an end and that the Japanese contribution of $\$ 1$ billion towards the construction of nuclear reactors under the Korean Peninsula Energy Development Organisation (KEDO) agreement would be halted temporarily. Externally, Japan strengthened security ties with South Korea and the United States.

${ }^{80}$ CRS, North Korea: Economic Sanctions.

${ }^{81}$ William J. Perry, Review of United States Policy Toward North Korea: Findings and Recommendations, October 12, 1999. <http://www.gwu.edu/ nsarchiv/NSAEBB/NSAEBB87/nk20.pdf>. (Hereinafter cited as Perry, Review of United States Policy Toward North Korea.)

${ }^{82}$ Perry, Review of United States Policy Toward North Korea.

${ }^{83}$ Perry, Review of United States Policy Toward North Korea.

${ }^{84}$ Perry, Review of United States Policy Toward North Korea.

${ }^{85}$ CRS, North Korea: Economic Sanctions. The major export restriction in place during the Clinton Administration was the ban on all commercial exports to North Korea other than those intended to meet basic human needs, which greatly hindered DPRK access to U.S. goods. The regulations issued in June 2000 amended the Export Administration Regulations (EARs) so that "many items that previously had required a license were now eligible for export without a license; certain items on the Commerce Control List (CCL) moved from a policy of denial status to case-by-case review."

${ }^{86}$ CRS, Foreign Assistance to North Korea.

${ }^{87}$ CRS, North Korea: Economic Sanctions. "Following the November 29, 1987, destruction of Korean Air Lines 007 , in flight, by a bomb reportedly planted by two North Korean agents, Secretary of State George Shultz placed North Korea on the list of countries supporting international terrorism. Most elements of trade, Beneficiary Developing Country status, sales of items on the U.S. Munitions List, most foreign aid, Export-Import Bank funding, and support in international financial institutions are denied to countries found to be supporting international terrorism under the Export Administration Act of 1979. North Korea was added to the list effective January 20, 1988. Placement on the sec. $6(\mathrm{j})$ list not only results in the constriction of trade possibilities; placement also may trigger denial of beneficial trade designation (NTR or GSP), unfavorable tax status for investors, new limits on diplomatic relations, opposition in international financial institutions, and stricter licensing requirements for trade with the United States in food and medicine."

${ }^{88}$ CRS, Foreign Assistance to North Korea. In September 1995, North Korea requested international food assistance. Between 1995 and 2004, the U.N. World Food Program (WFP) delivered 3.7 million metric tons (MT) of food aid to North Korea. According to WFP statistics, North Korea received an additional 4.6 million metric tons from sources that are not channeled through the WFP.

${ }^{89}$ Perry, Review of United States Policy Toward North Korea.

${ }^{90}$ Agreed Framework, paragraph II subparagraph II.

${ }^{91}$ Agreed Framework, paragraph II subparagraph III. 
92 Department of State, Talking Points [the Agreed Framework]. In a classified document with talking points for a State Department discussion with the Russians, it is noted that "DPRK experts will visit Washington December 6-10 to discuss issues connected with the planned exchange of liaison offices. We have a number of difficult issues to resolve, including consular issues (citizenship and consular access) and the question of the harsh restrictions the DPRK places on foreign diplomats."

${ }^{93}$ Department of State, Talking Points [the Agreed Framework].

Chanlett-Avery, Emma. North Korea: U.S. Relations, Nuclear Diplomacy, and Internal Situation. Congressional Research Service. 17 January 2012.

<http://www.fas.org/sgp/crs/nuke/R41259.pdf>. (Hereinafter cited as CRS, Nuclear Diplomacy.)

"U.S. and North Korea Vow to Improve Ties." Los Angeles Times. 10/13/2000.

$<$ http://articles.latimes.com/2000/oct/13/new/mn-36035>. (Hereinafter cited as Los Angeles Times, U.S. and North Korea Vow to Improve Ties).

${ }^{94}$ US-Japan-Korea Trilaterals.

${ }^{95}$ Los Angeles Times, U.S. and North Korea Vow to Improve Ties.

${ }^{96}$ U.S. Department of State. Memorandum, Stanley Roth to Secretary of State Albright, Subject: Your Visit to Pyongyang, DPRK. October 19, 2000. Available at <http://www.gwu.edu/ nsarchiv/NSAEBB/NSAEBB164/EBB\%20Doc\%2017.pdf>.

${ }^{97}$ Press Conference, Pyongyang, Democratic People's Republic of Korea, October 24, 2000 <http://www.gwu.edu/ nsarchiv/NSAEBB/NSAEBB164/10_24_00\%20Albright\%20press\%20conference\%2 0in\%20North\%20Korea.pdf>. "I came to Pyongyang to convey directly to Chairman Kim Jong II the views of President Clinton and to prepare for a possible visit by the President to the DPRK."

${ }^{98}$ U.S. Department of State. State Department Paper, Talking Point for S/Ivanov Telephone Call, Tuesday 10/29/00, [document incorrectly dates telephone call in August], ca October 23, 2000.<http://www.gwu.edu/ nsarchiv/NSAEBB/NSAEBB164/EBB\%20Doc\%2020.pdf> "My trip to Pyongyang was the next step in a process begun by the Perry mission nearly two years ago. I could visit North Korea because of the progress made in the Perry process and because of the efforts of President Kim Dae Jung, whose commitment to engagement was ultimately recognized in Pyongyang as sincere...I raised issues of concern to the U.S., including missiles, nuclear matters, terrorism, human rights and many others. I also urged the North to continue progress on North-South relations and to address Japanese concerns. I am satisfied we made a good beginning. Much work lies ahead."

${ }^{99}$ Press Briefing by Richard Boucher at Koryo Hotel, Pyongyang, Democratic People's Republic of Korea, October 23, 2000.

<http://www.gwu.edu/ nsarchiv/NSAEBB/NSAEBB164/10_24_00\%20Boucher\%20Press\%20Briefing\%20at \%20Koryo\%20Hotel.pdf>.

${ }^{100}$ Los Angeles Times, U.S. and North Korea Vow to Improve Ties.

${ }^{101}$ Harrison, Time to Leave. 
${ }^{102}$ Agreed Framework, paragraph III.

${ }^{103}$ Agreed Framework, paragraph III subparagraph I.

104 Oberdorfer, The Two Koreas, 257-260. “American nuclear weapons had been stationed on the territory of South Korea for more than three decades, since President Eisenhower authorized the deployment of nuclear warheads on Honest John missiles and 280-millimeter long-range artillery in December 1957...By 1972, according to U.S. documents obtained by nuclear researcher William Arkin, 763 nuclear warheads were deployed in South Korea, the peak number ever recorded." A reduction of nuclear weapons began during the Carter Administration (1977-1981) and by the end of 1991, all U.S. nuclear weapons had been removed from the South.

105 Harrison, Time to Leave.

${ }^{106}$ Oberdorfer, The Two Koreas, 257. The first U.S.-ROK Team Spirit military exercise began in June 1976 and "involved large-scale movements of troops and practice for use of nuclear weapons." The exercise has been an annual occurrence since the 1970s with few exceptions. Joint U.S.-ROK military exercises have also been referred to as Reception, Staging, Onward movement, and Integration (RSOI), Foal Eagle and more recently as Key Resolve.

${ }^{107}$ Oberdorfer, The Two Koreas, 273.

108 Perry, Review of United States Policy Toward North Korea. "In the course of the review, the policy team conferred with U.S. military leaders and allies, and concluded that, as in 1994, U.S. forces and alliances in the region are strong and ready. Indeed, since 1994, the U.S. has strengthened both its own forces and its plans and procedures for combing forces with allies. We are confident that allied forces could and would successfully defend ROK territory. We believe the DPRK's military leaders know this and thus are deterred from launching an attack."

109 "US plans big S Korea troops cuts." BBC Summary of World Broadcasts. 6/07/2004. <http://news.bbc.co.uk/2/hi/asia-pacific/3782213.stm>.

${ }^{110}$ Calder, Kent E. "The New Face of Northeast Asia." Foreign Affairs, January/February 2001. <http://www.foreignaffairs.com/articles/56660/kent-e-calder/the-new-face-of-northeast-asia>. (Hereinafter cited as Calder, The New Face of Northeast Asia). "A central feature of American policy towards Northeast Asia is the presence of more than 80,000 U.S. troops based in Japan, South Korea, and aboard the Seventh Fleet in the Pacific. These are by far the largest non-NATO American forces outside the United States and constitute the great bulk of American troops in the entire Pacific."

${ }^{111}$ Calder, The New Face of Northeast Asia.

112 Perry, Review of United States Policy Toward North Korea.

${ }^{113}$ Perry, Review of United States Policy Toward North Korea.

${ }^{114}$ U.S. Department of State. Four-Party Talks on the Korean Peninsula, 1997-98. December 2, 1998. Available at <http://www.state.gov/www/regions/eap/korea_4party_talks_1997.html>. (Hereinafter cited as Department of State, Four-Party Talks.) 
${ }^{115}$ Department of State, Four-Party Talks. Three "preparatory talks" preceded the plenary talks and ran from August 1997 through November 1997.

${ }^{116}$ Department of State, Four-Party Talks. U.S. troop withdrawal and an exclusive U.S.-DPRK peace agreement were two issues that were pushed heavily by North Korea since the first preparatory talk and the State Department noted continuing disagreements over the agenda because of these issues.

117 "North says four-way talks failed due to "unreasonable" US attitude." BBC Summary of World Broadcasts. 8/14/1999. (Original Source: Central Broadcasting Station Pyongyang 8/12/99)

118 "Four-way Korean peace talks likely to remain stalled, scholars say." The Korea Herald. 10/16/1999.

${ }^{119}$ Harrison, Time to Leave.

${ }^{120}$ Harrison, Time to Leave. North Korea proposed a "stopgap peace agreement," with the United States in 1998 prior to the missile launch, hoping to resolve the issue bilaterally.

${ }^{121}$ Martin, Under the Loving Care, 124. "Many South Korean and Western analysts argued that the militarization drive represented nothing but Kim's continuing dream of military conquest of the South. The North, on the other hand, always maintained that it arose from the prospect that South Korea and its American backer would start a new war and Pyongyang would have to defend itself. My view is that Kim's policy combined offensive and defensive elements - although his defensive concerns to a large extent represented his fears of the consequences of his offensive policies. Despite military alliances with China and the USSR, and Khruschev's assurances of protection, Kim feared he might not be able to count on allies to rescue him in case his contest with the South should lead to renewed war with the Americans. Without an impenetrable defense, he could not feel secure in taking offensive measures."

${ }^{122}$ Kim, II Sung, On the Juche Idea (Excerpts). Pyongyang: Foreign Languages Publishing House, 1979, 285. Excerpt taken from: Kim il-Sung Selected Works, $2^{\text {nd }}$ Eng. Ed., Vol. V, p. 489.

${ }^{123}$ Armstrong, Charles K. The North Korean Revolution, 1945-1950. Ithaca and London: Cornell University Press, 2003.

${ }^{124}$ Harrison, Time to Leave.

${ }^{125}$ Agreed Framework, paragraph III subparagraph II.

1992 Joint Declaration.

${ }^{127}$ Agreed Framework, paragraph III subparagraph III.

${ }^{128}$ US-Japan-Korea Trilaterals.

${ }^{129}$ U.S. Department of State. Memorandum, Roy to Secretary of State Albright, Subject: Pyongyang at the Summit, Subject: Pyongyang at the Summit. 16 June 2000. Available at <http://www.gwu.edu/ nsarchiv/NSAEBB/NSAEBB164/EBB\%20Doc\%2016.pdf>. (Hereinafter cited as Department of State, At the Summit.) 
${ }^{130}$ Department of State, At the Summit.

${ }^{131}$ Oberdorfer, The Two Koreas, 407-408.

${ }^{132}$ Calder, The New Face of Northeast Asia.

${ }^{133}$ Calder, The New Face of Northeast Asia.

${ }^{134}$ Calder, The New Face of Northeast Asia.

${ }^{135}$ Calder, The New Face of Northeast Asia.

${ }^{136}$ Press Availability after Trilateral Meeting, Seoul, South Korea, October 25, 2000 <http://www.gwu.edu/ nsarchiv/NSAEBB/NSAEBB164/10_25_00\%20Albright\%20Press\%20Availability\%2 Oafter\%20Trilateral\%20Meeting.pdf>.

137 Oberdorfer, The Two Koreas, 407-408. The "Sunshine Policy" was a "program of engaging the North through positive gestures and lowered barriers to trade and other official and unofficial interactions."

${ }^{138}$ Department of State, Talking Points [the Agreed Framework]. In a classified document with talking points for a State Department discussion with the Russians, it is noted that "DPRK experts will visit Washington December 6-10 to discuss issues connected with the planned exchange of liaison offices. We have a number of difficult issues to resolve, including consular issues (citizenship and consular access) and the question of the harsh restrictions the DPRK places on foreign diplomats."

${ }^{139}$ Department of State, Talking Points [the Agreed Framework].

${ }^{140}$ Agreed Framework, paragraph IV.

${ }^{141}$ Agreed Framework, paragraph IV subparagraph I.

${ }^{142}$ Agreed Framework, paragraph IV subparagraph II. "Upon conclusion of the supply contract for the provision of the LWR project, ad hoc and routine inspections will resume under the DPRK's Safeguards Agreement with the IAEA with respect to the facilities not subject to the freeze. Pending conclusion of the supply contract, inspections required by the IAEA for the continuity of safeguards will continue at the facilities not subject to the freeze."

${ }^{143}$ Agreed Framework, paragraph I subparagraph III.

${ }^{144}$ Agreed Framework, paragraph I subparagraph III.

${ }^{145}$ U.S. Department of State. Bureau of Intelligence and Research (INR). DPRK Nuclear Status. 20 December 1996. <http://www.gwu.edu/ nsarchiv/NSAEBB/NSAEBB164/EBB\%20Doc\%2014.pdf>. (Hereinafter cited as Department of State, DPRK Nuclear Status.)

${ }^{146}$ Agreed Framework, paragraph IV subparagraph III.

${ }^{147}$ United Nations, International Atomic Energy Agency. The DPRK's Violation of its NPT Safeguards Agreement with the IAEA, 1997. <http://www.gwu.edu/ nsarchiv/NSAEBB/NSAEBB87/nk18.pdf>. 
${ }^{148}$ Oberdorfer, The Two Koreas, 289-90. "If it were working well, Yongbyon's only operating reactor, rated at 5 megawatts ( 5 million watts), would produce only enough electricity to power perhaps five large American office buildings; but two standard LWRs would produce 2,000 megawatts - nearly enough electricity to power the Washington metropolitan area."

${ }^{149}$ US-Japan-Korea Trilaterals. A State Department report noted that "Good progress is being made on the implementation of the nuclear aspects of the Agreed Framework. Most importantly, in late April (1996), with all the complex technical preparations complete, the actual canning of spent fuel began at Nyongbyon under IAEA observation."

${ }^{150}$ Department of State, DPRK Nuclear Status.

${ }^{151}$ U.S. Department of State, Key Issue Paper for Secretary of State-designate Madeline Albright, Subject: Korean Peninsula Issues, December 1996. <http://www.gwu.edu/ nsarchiv/NSAEBB/NSAEBB164/EBB\%20Doc\%2013.pdf>.

${ }^{152}$ Sigal, Disarming Strangers, 9.

${ }^{153}$ Agreed Framework, paragraph I subparagraph I.

${ }^{154}$ The People's Korea, Stalemated LWR Project.

${ }^{155}$ Central Intelligence Agency. Exploring the Implications of Alternative North Korean Endgames: Results for a Discussion Panel on Continuing Coexistence Between North and South Korea. 21 January 1998, 6. Available at <http://www.gwu.edu/ nsarchiv/NSAEBB/NSAEBB205/Document\%20No\%2014.pdf>. (Hereinafter cited as CIA Intelligence Report, January 1998.) "Opinion ranged from as few as 2 years to possibly as long as 10 years but most participants seemed uncomfortable with the notion that North Korea could muddle through for more than 5 years."

${ }^{156} \mathrm{CIA}$ Intelligence Report, January 1998, 4.

${ }^{157}$ Cha, Victor and Kelly, James. "Pyongyang Blues." Foreign Affairs, March/April 2008. <http://www.foreignaffairs.com/articles/63228/victor-cha-and-james-kelly/pyongyang-blues.> (Hereinafter cited as Cha \& Kelly, Pyongyang Blues.) "When President Bush entered office in January 2001, there was a comprehensive review policy toward North Korea, and at its conclusion, he directed his team to 'undertake serious discussion with North Korea on a broad agenda.' The review affirmed the 1994 Agreed Framework. As then Secretary of State Colin Powell repeatedly stated, the administration was prepared to meet the North Koreans 'anytime, and anyplace' with an open agenda."

${ }^{158}$ Laney \& Shaplen, How to Deal. According to Laney and Shaplen, the Bush Administration, "considered the accord a form of blackmail signed by his predecessor - even though, after a long review of North Korea policy in 2001, the Bush administration found it could not justify abandoning the pact without having something better with which to replace it."

159 "Court Overturns Recounts, Giving Bush the Presidency; Divided Justices Cite Concerns With Timeframe." The Washington Post. 12/13/2000. 
${ }^{160}$ KEDO, 2001 Annual Report. "From August 1, 2001, through December 31, 2001, KEDO continued work on the light-water reactor (LWR) project at the Kumho site under the Turnkey Contract (TKC) with the Korea Electric Power Corporation (KEPCO). Construction of the LWR plants entered an important new phase when in late August site grading was completed. This enabled excavation of the foundations for the main power plant buildings to begin in early September, following the issuance of the Construction Permit by the DPRK on September 1, 2001. A small ceremony to commemorate site excavation was held on September 14, 2001, with attendance by officials from KEDO, its contractors and subcontractors, and the DPRK. As of December 31, 2001, over 1,100 personnel were working at the Kumho site."

161 “KEDO Marks 'First Concrete' Pouring Milestone.” KEDO. 7 August 2002. <http://www.kedo.org/news_detail.asp?NewsID=22>. "On Wednesday, August 7, 2002, the Korean Peninsula Energy Development Organization (KEDO) will mark an important milestone in the construction of the Light-Water Reactor (LWR) project at the construction site in Kumho District, South Hamgyong Province, the Democratic People's Republic of Korea (DPRK). A ceremony will be held to commemorate the pouring of "first concrete" for the foundations of the main power plant buildings."

Korean Peninsula Energy Development Organization. 2002 Annual Report. 31 December 2002. <http://www.kedo.org/pdfs/KEDO_AR_2002.pdf>. (Hereinafter cited as KEDO, 2002 Annual Report.) "From January 1, 2002, through December 31, 2002, KEDO continued work on the light-water reactor (LWR) project at the LWR site under the Turnkey Contract (TKC) with the Korea Electric Power Corporation (KEPCO). Construction of the LWR plants entered an important new phase when, in early August, first concrete was poured for the Unit 1 Reactor Containment Building. KEDO held a major ceremony to commemorate the first concrete pouring on August 7 at the LWR site. Representatives of all the Executive Board members, senior representatives from KEDO members, senior staff from the Secretariat, KEDO contractors and subcontractors, international media, and DPRK officials attended. As of December 31, 2002 , the LWR project was approximately $28 \%$ complete, and over 1,400 personnel were working at the LWR site."

${ }^{162}$ Korean Peninsula Energy Development Organization. 2004 Annual Report. 31 December 2004. <http://www.kedo.org/pdfs/KEDO_AR_2004.pdf>. (Hereinafter cited as KEDO, 2004 Annual Report.) According to KEDO, by 2003 construction was reported to be only a third of the way complete.

${ }^{163}$ KEDO, 2002 Annual Report.

${ }^{164}$ CRS, Nuclear Diplomacy. "Under the Bush Administration, Ambassador Christopher Hill reportedly discussed an exchange of liaison offices. This did not lead to an offer of full diplomatic relations pursuant to negotiations in the Six-Party Talks."

${ }^{165}$ Bush, State of the Union Address.

${ }^{166}$ Bush, State of the Union Address.

${ }^{167}$ Clinton, Letter to Kim Jong II.

${ }^{168}$ Kagan, Robert. "The September 12 Paradigm: America, the World, and George W. Bush." Foreign Affairs, September/October 2008. <http://www.jstor.org.proxy.its.virginia.edu/stable/20699302>. (Hereinafter cited as Kagan, September 12 Paradigm.)

${ }^{169}$ Kagan, September 12 Paradigm. 
${ }^{170}$ CRS, North Korea: Economic Sanctions.
${ }^{171}$ Kagan, September 12 Paradigm.
${ }^{172}$ Cha \& Kelly, Pyongyang Blues.
${ }^{173}$ Korean Peninsula Energy Development Organization. 2003 Annual Report. 31 December 2003. <http://www.kedo.org/pdfs/KEDO_AR_2003.pdf>. "Consistent with the Executive Board's decision of November 14, 2002, KEDO made no deliveries of heavy fuel oil to the DPRK in 2003."

${ }^{174}$ KEDO, History.

${ }^{175}$ Central Intelligence Agency. The World Factbook: North Korea. 24 February 2009. Available at <https://www.cia.gov/library/publications/download/download-2009/index.html>. (Hereinafter cited as CIA, World Factbook.)

${ }^{176}$ KEDO, 2004 Annual Report.

177 KEDO, 2004 Annual Report. The suspension would be effective December 1, 2004.

${ }^{178}$ KEDO, History.

${ }^{179}$ KEDO, History. The termination of the LWR program took place in May 2006, but "serious discussion" by the Executive Board to terminate the project began in November 2005.

${ }^{180}$ CRS, North Korea: Economic Sanctions. Introduced by Senator Kyl on January 13, 2003 and referred to the Committee on Foreign Relations.

${ }^{181}$ CRS, North Korea: Economic Sanctions. "The Senate passed the amended H.J.Res. 2 by a vote of 69 - 29 and appointed conferees on January 23, 2003," and the resolution provided "appropriations to several departments, agencies, and offices of the U.S. government for Fiscal Year 2003..."

182 United Nations. UN Security Council Resolution 1540. 28 April 2004.

<http://www.globalpolicy.org/images/pdfs/0428res1540.pdf>.

${ }^{183}$ Agreed Framework, paragraph III subparagraph II.

1841992 Joint Declaration, point III.

185 "S. Korea Nuclear Project Detailed." The Washington Post. 9/12/2004. <http://www.washingtonpost.com/ac2/wp-dyn/A14633-2004Sep11.> (Hereinafter cited as Washington Post, South Korea Nuclear Project.)

${ }^{186}$ United Nations, International Atomic Energy Agency. Implementation of the NPT Safeguards Agreement in the Republic of Korea. <http://www.iaea.org/Publications/Documents/Board/2004/gov2004-84.pdf>. (Hereinafter cited as IAEA, South Korea Safeguards.) 
${ }^{187}$ Washington Post, South Korea Nuclear Project.

${ }^{188}$ Washington Post, South Korea Nuclear Project.

${ }^{189}$ IAEA, South Korea Safeguards.

${ }^{190}$ Agreed Framework, paragraph III.

${ }^{191}$ Central Intelligence Agency, Untitled, November 2002.

<http://www.gwu.edu/ nsarchiv/NSAEBB/NSAEBB87/nk22.pdf> "We continue to monitor and assess the North's nuclear weapons efforts, which given the North's closed society and the obvious covert nature of the program, remains a difficult intelligence collection target."

192 "Bush's North Korea Surrender Will Have Lasting Consequences." The Wall Street Journal. 10/13/2008 <http://online.wsj.com/article/SB122385733887027383.html\#printMode>. (Hereinafter cited as Wall Street Journal, Korea Surrender Will Have Lasting Consequences.)

193 Laney \& Shaplen, How to Deal.

${ }^{194}$ Harrison, Did North Korea Cheat?

195 “Wall Street Journal, Korea Surrender Will Have Lasting Consequences.

${ }^{196}$ Cha, Victor. "Engaging North Korea Credibly." Survival, 42:1 Summer 2002, 136-155.

${ }^{197}$ CIA, World Factbook.

${ }^{198}$ Bolton, John and Kelly, James A. "The Great Debate: Can North Korea Be Stopped?” The National Interest, November/December 2008. <http://nationalinterest.org/greatdebate/north-korea-stopped3808>. 